\title{
ACPD
}

\section{Analysis of a strong wildfire event over Valencia (Spain) during Summer 2012 \\ - Part 1: Aerosol microphysics and optical properties}

J. L. Gómez-Amo ${ }^{1,2}$, V. Estellés ${ }^{1}$, S. Segura ${ }^{1}$, C. Marcos ${ }^{1}$, A. R. Esteve ${ }^{1,3}$, R. Pedrós ${ }^{1}$, M. P. Utrillas ${ }^{1}$, and J. A. Martínez-Lozano ${ }^{1}$

${ }^{1}$ Departament de Física de la Terra i Termodinàmica, Universitat de València, Burjassot, Spain ${ }^{2}$ Laboratory for Earth Observations and Analyses, ENEA, Rome, Italy

${ }^{3}$ Department of Meteorology, University of Reading, RG6 6BB, Reading, UK

Received: 25 July 2013 - Accepted: 23 August 2013 - Published: 30 August 2013

Correspondence to: J. L. Gómez-Amo (jlgomeza@uv.es)

Published by Copernicus Publications on behalf of the European Geosciences Union.

Title Page

Abstract

Introduction

Conclusions

References

Tables

Figures

14

$\rightarrow 1$

4

Back

Close 


\section{Abstract}

The most intense wildfire experienced in Eastern Spain since 2004 happened in Valencia during summer 2012. Although the fire was mostly active during days 29-30 June, a longer temporal period (from 24 June to 4 July) was selected for this analysis. 5 Column-integrated, vertical resolved and surface aerosol observations were performed continuously at the Burjassot station throughout the studied period. The aerosol optical depth at $500 \mathrm{~nm}$ shows values larger than 2 for the most intense part of the wildfire and an extremely high maximum of 8 was detected on 29 June. The simultaneous increase of the Ångström exponent was also observed, indicating the important contribution of small particles in the smoke plume.

An extraordinary increase in the particle concentration near the ground was observed and hence the measured scattering coefficient was drastically enhanced. The scattering coefficient and the $\mathrm{PM}_{2.5}$ level maxima reached the unusually high values of $2100 \mathrm{Mm}^{-1}$ and $160 \mathrm{\mu g} \mathrm{m}^{-3}$, respectively. These records represent an enhancement factor of 26 and 7 with respect to the climatological averages found in this station during June and July. The surface maxima were observed with 1-day lag from the maximum AOD, and this fact is linked with the mixing layer amplitude and the sedimentation of smoke particles.

The aerosol microphysical parameters and optical properties were determined for the whole period by combination of an inversion procedure and the Mie Theory. The smoke particles enhanced drastically the volume concentration of the fine mode with a maximum of $0.4 \mu^{3} \mu^{-2}$, which is 10 times higher than the climatological summer background in this site. The simultaneous presence of dust and smoke particles at different altitudes was observed and hence the coarse mode was also significant during the most intense period of the wildfire episode. Therefore the aerosol single scattering albedo and the asymmetry parameter obtained during the smoke cases display high variability which is partially modulated by the volume of coarse particles.
ACPD

13, 22639-22685, 2013

Aerosol

microphysics and optical properties

J. L. Gómez-Amo et al.

Title Page

Abstract

Introduction

Conclusions

References

Tables

Figures

14

$\rightarrow 1$

4

Back

Close 
The smoke episode highly contributed to increase the load of particles remaining in the atmosphere after the event, especially in the fine mode, although similar aerosol microphysical and optical properties were observed before and after the event. In addition, the particle concentration observed at surface level due to the wildfire episode 5 largely contributes to exceed the EU annual limits for the particulate matter in the studied region.

\section{Introduction}

The biomass burning aerosols affecting the Mediterranean region during summer are mostly local due to the warm and dry Mediterranean climate which favors the ignition 10 and spread of fires. These wildfires suppose a big source of particles with biomass origin which can affect the air quality or the local meteorology in the places near the emission source. In general these events affect the site for a short period time, of the order of days or weeks.

Particle emissions as a consequence of wildfires have a great impact over both cli15 mate and air quality (Yokelson et al., 2007; Andreae and Crutzen, 1997; Andreae et al., 2004). Visibility of affected areas can be strongly reduced during wildfire periods, and their effects in population's health may be important as well. Moreover, fires are considered as a source of CCN particles and can influence cloud formation or precipitations (Luderer et al., 2006; Trentmann et al., 2006; Kivekäs, 2008: Reid et al., 2005; Reutter et al., 2004; Feingold et al., 2001; Rosenfeld et al., 2008).

Emitted particles due to biomass burning are dominated by the accumulation mode and can be described with a lognormal size distribution (Seinfeld and Pandis, 2006) with an average diameter between $100-150 \mathrm{~nm}$, together with two small modes, a coarse mode and, occasionally, a nucleation mode (Reid et al., 2005). Their composition depends both on the combustion material as on the combustion process itself. Coarse mode particles consists on dust, aggregates of carbon, ashes and unburnt material portions (Hugershoefer et al., 2008; Formenti et al., 2003; Gaudichet et al., 1995),
ACPD

13, 22639-22685, 2013

Aerosol

microphysics and optical properties

J. L. Gómez-Amo et al.

Title Page 
while accumulation mode consists mainly on organic matter with a $10 \%$ of soot and a $10 \%$ of inorganic species (Reid et al., 2005).

Fine particles, typical of fire events, are associated to adverse health effects such as an increase in respiratory illnesses, asthma, bronchitis and eye irritation (Laden et 5 al., 2000; Pope et al., 2002; WHO, 2002, 2003). Importance of exposure depends on the wind direction, fire intensity and precipitation. This makes difficult to ensure the temporal and spatial extent of population exposed to smoke emissions based only in air quality measurements at ground level (Liu et al., 2009).

Moreover, biomass burning plays an important role in climate and is considered the 10 second anthropogenic aerosol source (McKendry et al., 2011). Aerosols produced as a consequence of forests, pastures, and crops burning scatter and absorb solar radiation (direct effect), while they also affect cloud formation acting as cloud condensation nuclei (indirect effect). Also, they are considered as a source of air pollution which degrades considerably regional visibility (Pahlow et al., 2005).

15 Aerosol optical properties during the fire events have already been analyzed in the scientific literature from different points of view and employing different measurement techniques. In example, big scale fire events were studied through in situ measurements in North America (Hobbs et al., 1996), Brasil (Andreae et al., 1996; Kaufman et al., 1998) and Africa (Eck, 2001). Other authors combined in situ and vertical columnintegrated measurements (e.g. Balis et al. 2003). Moreover, the combination of lidar measurements with aerosol absorption can potentially help to estimate the aerosol load over an area (e.g. Amiridis et al., 2011; Mariano et al., 2010).

On the other hand, dense aerosol plumes are easily detected and visualized using remote sensing techniques. Therefore, the information obtained from satellites can be useful in order to monitor spatial and temporal trends of particle concentrations over large geographic areas making possible to study their transport and transformations. Since 1999, National Aeronautics and Space Administration (NASA) has launched a series of satellite sensors as part of the Earth Observing System (EOS), including the Multiangle Imaging Spectro Radiometer (MISR) (Diner et al., 2002) and the Moderate

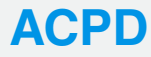

13, 22639-22685, 2013

Aerosol

microphysics and optical properties

J. L. Gómez-Amo et al.

Title Page

Abstract

Introduction

Conclusions

References

Tables

Figures

14

$\rightarrow 1$

4

Back

Close

Printer-friendly Version

Interactive Discussion 
Resolution Imaging Spectroradiometer (MODIS) (Salomonson et al., 1989). Both of them can provide the size and quantity of aerosols both over land and ocean with a nearly global coverage and a moderate spatial resolution. Moreover, MISR is able to provide information about aerosol type and smoke plumes height (Kahn et al., 2008).

5 Aerosol observation through MISR and MODIS can provide quantitative measurements about severity of these events and their potential impact in air quality.

This work deals with the analysis of an intense wildfire which took place in Valencia region during the final days of June and firsts of July 2012. In terms of the burn extension it was the most destructive event that happened in Eastern Spain from 2004.

10 The measurements station of the University of Valencia located in Burjassot is $60 \mathrm{~km}$ distant of the combustion source. The closeness to the smoke emission source and the large set of instruments devoted to measure aerosols and radiation that are running routinely in the station provided a unique and interesting opportunity to monitor the smoke particles during the event. Therefore this work is addressed to analyze the 15 aerosol microphysical and optical properties by means of the combination of in situ, column-integrated and vertical resolved measurements. In a future work, the authors will quantify radiative impact produced by released aerosols during this wildfire.

\section{Site measurements, instrumentation and methodology}

The measurement station is located at the Physics Faculty $\left(39.508^{\circ} \mathrm{N}, 0.418^{\circ} \mathrm{W}, 60\right.$ $20 \mathrm{~m}$ a.s.l) in the Burjassot campus of the University of Valencia. Burjassot is a town of 35000 inhabitants within the Valencia metropolitan area whose total population is around 1400000 inhabitants. Given its proximity to the principal nucleus of Valencia $(5 \mathrm{~km})$, the measurement station is directly affected by the urban and industrial pollution typical of a metropolitan area. Its closeness to the western coast of the Mediterranean

25 Sea $(10 \mathrm{~km})$ also determines the type of aerosols in the region. Intensive agriculture is practiced, especially irrigated agriculture, although non-irrigated areas are also found inland. In summer, forest fires are not infrequent and can occasionally affect the char-

\section{ACPD}

13, 22639-22685, 2013

Aerosol

microphysics and optical properties

J. L. Gómez-Amo et al.

Title Page

Abstract

Introduction

Conclusions

Tables

References

Figures

14

$\rightarrow 1$

4

Back

Close

Printer-friendly Version

Interactive Discussion 
acteristics of the aerosols in the area. In addition, Saharan dust intrusions frequently occur, especially during the summer months (Estellés et al., 2007a).

The station is equipped with a large set of instruments devoted to monitor radiation, aerosols, clouds and different atmospheric components (ozone and water vapour). The 5 column-integrated aerosol optical properties and water vapour amount are determined by means of a Cimel CE318 and a Prede POM01 sun-photometers. The in situ aerosol scattering and absorption coefficients are measured by a TSI 3563 integrating nephelometer and a Magee Scientific AE-31 aethalometer, respectively. The vertical profile of aerosol backscattering and extinction are determined by a Cimel CAML CE370-2 10 microlidar. In addition, the integrated solar radiation components are measured by two Kipp and Zonen CMP21 pyranometres, for the global and diffuse; and two pyrheliometers for the direct (Kipp and Zonen CHP1 and Eppley NIP). The atmospheric thermal radiation is measured by a Kipp and Zonen CGR4 pyrgeometer. All these radiometers are mounted on a Kipp and Zonen solar tracker (SOLYS-2). An all sky camera (Sieltec 15 SONA) is used to determine the cloud cover. Due to different reasons the Prede radiometer and the aethalometer were not operational during the wildfire episode. Only the instrumentation used in this study is described in detail next.

\subsection{Cimel CE318 sun-photometer}

The sun-photometer Cimel CE318 operates within the Red Ibérica de Medida de 20 Aerosoles (RIMA, 2013) and also takes part of AERONET network (Holben et al., 1998) and ESR network (Campanelli et al., 2012). The Cimel is equipped with a double collimator with a $1.2^{\circ}$ Field of View (FOV) that allows automatic measurements of direct sun intensity in eight spectral channels (340, 380, 440, 500, 675, 870, 940 and $1020 \mathrm{~nm}$ ) and the sky radiance in four of them $(440,675,870$ and $1020 \mathrm{~nm})$. The Full Width at 25 Half Maximum (FWHM) of the visible and near infrared channels is $10 \mathrm{~nm}$, and $2 \mathrm{~nm}$ for the ultraviolet channels. The $940 \mathrm{~nm}$ channel is dedicated to obtaining the columnar water vapour content (CWV) (Bruegge et al., 1992), and the rest of them are used to determine the aerosol optical properties. The aerosol optical depth (AOD) typical un-
ACPD

13, 22639-22685, 2013

Aerosol

microphysics and optical properties

J. L. Gómez-Amo et al.

Title Page

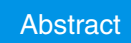

Introduction

Conclusions

References

Tables

Figures

14

- I

4

Back

Close

Full Screen / Esc

Printer-friendly Version

Interactive Discussion 
certainties are between 0.01 and 0.02 , although it strictly changes with the solar height and wavelength (Estellés et al., 2006).

During the wildfire event there were problems with the transmission of data to AERONET, especially on 29 and 30 June. Therefore, an independent way to process

5 the raw data following the methodology proposed by Estellés et al. (2012) for the European Skynet Radiometers (ESR) network was used to obtain the spectral AOD, the Ångström Exponent $(\mathrm{AE})$ and $\mathrm{CWV}$ amount. Although the differences for $\mathrm{AOD}, \mathrm{AE}$ and CWV between ESR and the AERONET are smaller than 0.003 and 0.02 and $0.02 \mathrm{~cm}$ respectively, the ESR.pack was used for the complete period in order to homogenise 10 the retrieval. Initially the cloud screening algorithm by Smirnov et al. (2000) was also applied for all data. However, due to the high variability of the smoke amount observed on 29 and 30 June no values passed the standard cloud screening. Since the most intense period of the wildfire episode occurred during these days and their data contain the most valuable information the cloud screening filter was then removed. Therefore the all sky camera images and the MSG/SEVIRI Level-1 browse imagery for visible and infrared channels were visually inspected in order to remove manually the cloudy periods at the Cimel measurement time.

\subsection{TSI 3563 integrating nephelometer}

The total aerosol scattering $\left(\sigma_{\mathrm{sp}}\right)$ and backscattering $\left(\sigma_{\mathrm{bsp}}\right)$ coefficients at ground level 20 were measured using a TSI Model 3563 three-wavelength $(\lambda=450,550,700 \mathrm{~nm})$ integrating nephelometer (Anderson et al., 1996; Heintzenberg and Charlson, 1996). This instrument draws a sample of ambient air through an inlet, illuminates it with a halogen lamp, and measures the scattered light using photomultiplier tubes. The scattered light is integrated over an angular range which can be adjusted to either $7-170^{\circ}$ or $90-170^{\circ}$ 25 by means of a backscatter shutter in order to give the total scatter or backscatter signal, respectively. The pressure and temperature are measured inside the nephelometer, so the scattering by air molecules can be calculated and then subtracted from the total

\section{ACPD}

13, 22639-22685, 2013

Aerosol

microphysics and optical properties

J. L. Gómez-Amo et al.

Title Page

Abstract

Introduction

Conclusions

References

Tables

Figures

14

$\rightarrow 1$

4

Back

Close

Printer-friendly Version

Interactive Discussion 
scattering to determine the scattering by aerosols. The relative humidity is also measured inside the nephelometer.

The measurements were made at ambient relative humidity without aerosol cut-off at about $15 \mathrm{~m}$ above the ground. The nephelometer's averaging time was $5 \mathrm{~min}$, and the

5 zero signal was measured every hour during $5 \mathrm{~min}$. The flow rate was fixed at $30 \mathrm{I} \mathrm{min}^{-1}$. Calibration of the nephelometer is carried out at least twice a year (every 4-6 months) using $\mathrm{CO}_{2}$ as high span gas and filtered air as low span gas. Uncertainty in the nephelometer measurements considering angular truncation errors, non-lambertian nature of the light source, wavelength non-idealities, and calibration uncertainties is approx10 imately $7 \%$ (Anderson et al., 1996; Anderson and Ogren, 1998). The scattering data were adjusted to conditions of standard temperature $\left(0^{\circ} \mathrm{C}\right)$ and pressure $(1013 \mathrm{hPa})$. Due to design limitations, scattering measurements do not cover the full angular range $\left(0-180^{\circ}\right)$, and a nephelometer truncation correction for particles with "no size cut" is applied to the data (Anderson and Ogren, 1998).

In addition, the scattering Ångström exponent $\left(\alpha_{\mathrm{s}}\right)$ was determined from the spectral measurements of $\sigma_{\mathrm{sp}}$ following (1).

$\alpha_{\mathrm{s}}=-\frac{\ln \left(\sigma_{\mathrm{sp}}^{450 \mathrm{~nm}} / \sigma_{\mathrm{sp}}^{700 \mathrm{~nm}}\right)}{\ln (450 / 700)}$

Additional details of the operational measurements of the integrating nephelometer can be found in Esteve et al. (2012).

\subsection{Cimel CAML CE370-2 microlidar}

The CAML CE 370-2 lidar system, manufactured by CIMEL ELECTRONIQUE, is a monochromatic elastic lidar operating at $532 \mathrm{~nm}$. The lidar signal is generated by a Qswitched frequently-doubled Nd:YAG laser, with an output energy lying between 8 and $20 \mu \mathrm{J}$ and pulse repetition frequency of $4.7 \mathrm{kHz}$. The laser light travels through a fiber

ACPD

13, 22639-22685, 2013

Aerosol

microphysics and optical properties

J. L. Gómez-Amo et al.

Title Page

Abstract

Introduction

Conclusions

References

Tables

Figures

14

$\rightarrow 1$

4

Back

Close

Full Screen / Esc

Printer-friendly Version

Interactive Discussion 
optic cable to the lidar telescope, where the beam is expanded to ensure eye-safety before being emitted.

A $20 \mathrm{~cm}$ diameter refractive telescope is used for both reception and emission, with a focal length of approximately $1 \mathrm{~m}$ and a field of view of $55 \mu \mathrm{rad}$. This narrow field 5 of view eliminates most multiple scattering problems and limits the background solar signal in the detection phase. The backscattered signal in the atmosphere received by the telescope is transmitted back through the fiber optic cable to the detection system, consisting of a narrow bandpass interference filter and an avalanche photodiode photocounting module.

10 Due to its configuration, the maximum vertical range of the CAML CE 370-2 lidar is $30 \mathrm{~km}$, with a maximum vertical spatial resolution of $15 \mathrm{~m}$. The full overlap is reached at approximately $2 \mathrm{~km}$. However, an overlap correction function can be obtained from horizontal measurements as it is described by Berkoff et al. (2003). In our case, these measurements are performed twice every year, and the correction functions obtained enable us to use data from $500 \mathrm{~m}$.

The CAML lidar is programmed so that one vertical profile is retrieved every minute during measurement periods. For regular days, only three 30-min measurements periods are usually scheduled (approximately centered at 09:00, 12:00 and 15:00 UTC) to study the evolution of the boundary layer though the day. However, when a special event occurs (e.g. dust outbreak or forest fire), a continuous monitoring of the atmosphere is done. For the fire events in 2012 in Valencia, continuous measurements were performed during 29 and 30 June, for daytime hours.

Aerosol extinction profiles can be obtained from the lidar measurements using the two-component elastic lidar inversion algorithm (Fernald, 1984; Sasano and Nakane, 25 1984; Klett, 1985) and AOD simultaneously measured by the CIMEL sun-photometer during daytime cases. However, several profiles must be averaged in order to obtain an adequate signal-to-noise ratio.

\section{ACPD}

13, 22639-22685, 2013

Aerosol

microphysics and optical properties

J. L. Gómez-Amo et al.

Title Page

Abstract

Introduction

Conclusions

References

Tables

Figures

14

$\rightarrow 1$

4

Back

Close 


\section{Meteorological situation}

The wildfire episode started nominally on 28 June and was completely extinct eighteen days after. It has been considered the most severe wildfire event happened in Spain from 2004 , spanning a total burn surface of 48500 ha. In fact the fires occurred quasi5 simultaneously in two different places, Cortes de Pallás and Andilla, which are located in the Eastern part of the Iberian Peninsula. Both places are less than $60 \mathrm{~km}$ far of Valencia and the Mediterranean Sea. The most intense days around the metropolitan area of Valencia took place on 29 and 30 June, nevertheless the ashes were still falling down more than a week after. In order to analyze the variability of the meteorological

selected for the study.

The 96-h flight time back trajectories at three different altitudes (500, 1500 and $2500 \mathrm{~m}$ a.g.I) simulated with the Hybrid Single-Particle Lagrangian Integrated Trajectory Model (HYSPLIT) (Draxler and Rolph, 2013) (Fig. 1) and synoptic pressure maps (not shown) have been used to analyze the meteorological situation during the chosen period. During the days before the wildfire (26 June), a high pressure system was located North of the Iberian Peninsula, with a low pressure system approaching from the Atlantic to Europe. Also a high pressure system was located over Germany, compensated by low pressure systems located over the Iberian Peninsula. On 28 June, when the wildfire started, the low pressure gradient over the Atlantic deepened and moved towards Ireland while the high pressure system was displaced over the Western Mediterranean Sea. This dynamics generated a cyclonic circulation which favored the advection of the air mass from North Africa towards Southwestern Spain (Fig. 1a). On 29 June, the situation remained similar with the Atlantic low pressure system moving North and a high pressure system located over the Azores. This situation permitted the injection of Atlantic air masses at high altitudes from Southwestern Spain together with the persistent North African influence at $1500 \mathrm{~m}$ a.g.l. (Fig. 1b). After the fire event, on 3 June, the low pressure systems moved West of Ireland while the high pressure
ACPD

13, 22639-22685, 2013

Aerosol

microphysics and optical properties

J. L. Gómez-Amo et al.

Title Page

Abstract

Introduction

Conclusions

References

Tables

Figures

14

$\rightarrow 1$

4

Back

Close 
system kept moving to the East bringing on the arrival of the air mass from the Atlantic Ocean at high altitudes and the stagnation of the local circulation near the ground (Fig. 1c).

Figure 2 shows the quick response MODIS images on 28 and 29 June over Eastern 5 Spain. Clear differences are observed between both days. On 28 June, the effect of the dust layer reduces the surface contrast (Fig. 2a), while the magnitude of the wildfire can be clearly observed on 29 June (Fig. 2b), with the smoke plume following the prevailing Northeastern wind direction.

\section{Results}

$10 \quad 4.1$ Column-integrated observations

Figure 3 shows the time series of the AOD at $500 \mathrm{~nm}$ and the $A E$ measured by the Cimel CE318 sun photometer. The logarithmic scale on the $y$-axis has been used in order to appreciate better the AOD variability during the chosen period (Fig. 3a). The Cimel CAML CE370-2 microlidar vertical profile of the range corrected signal from 26 15 June to 1 July is shown in Fig. 4.

As it was mentioned in Sect. 3, the atmospheric situation around the Valencia region during the days before the beginning of the wildfire episode corresponded to a regular summer situation in Eastern Spain. The AOD and AE values ranged between 0.14-0.16 and 1.1-1.15, respectively, during 24 and 25 June. The strongest Saharan dust intrusion originated in the North of Africa that reached the Valencia region during June 2012 was on 26 June causing an increase of AOD from 0.25 to 0.63 throughout the day (Fig. 3a). Simultaneously, a decrease of AE was observed from 0.79 to 0.29 (Fig. 3b), indicating the presence of larger particles in the atmosphere. The dust particles remained in the atmosphere during 27 and 28 June, and the AOD was still increasing up to 0.78 while $A E$ reached a minimum of 0.10 on 28 June at 16:00 UTC. The presence of cirrus clouds on 27 June limited the amount of valid measurements

\section{ACPD}

13, 22639-22685, 2013

Aerosol

microphysics and optical properties

J. L. Gómez-Amo et al.

Title Page

Abstract

Introduction

Conclusions

References

Tables

Figures

14

$\rightarrow$

4

Back

Close

Full Screen / Esc

Printer-friendly Version

Interactive Discussion 
of $A O D$ and restricted them around noon. In addition, the lidar measurements confirm the presence of dust which is vertically distributed from the surface up to $4.5 \mathrm{~km}$ from 26 to 28 June (Fig. 4a).

The smoke plume from the wildfire was detected at the Burjassot station during the 5 afternoon of 28 June shortly after $16 \mathrm{~h}$ UTC causing a marked change in the aerosol properties. The last measurements of AOD and AE on 28 June present some quick variability, increasing suddenly from 0.78 to 3 and from 0.10 to 1.39 , respectively. These higher values of $A E$ suggest that the amount of smaller particles in the atmosphere was notably increased. Although the lidar seems to indicate that the dust and the smoke 10 plume, which was placed around 2-km altitude (Fig. 4a), may have coexisted in the atmosphere.

The strongest intensity of the smoke plume was observed on 29 June. AOD and AE showed high temporal variability all day long as a consequence of the inhomogeneity of the smoke plume. The AOD was largely enhanced during midday, between 11:35 and 14:40 UTC, remaining larger than 3. In addition, the presence of the smoke plume induced an extremely large AOD maximum of 8 , which was reached at 13:05 UTC. During the same period, the $A E$ remained higher than 1.85, indicating that the load of small particles became significant. Moreover, early in the morning and late in the afternoon the aerosol behavior was somewhat similar to the last measurements observed on 28 June, with the AOD ranging between 1.72 and 2.60 and the AE between 1.23 and 1.57. The ratio of smoke particles was reduced on 30 June. Nonetheless, the AOD remained highly variable, in the range $1-2$, whilst the $A E$ was larger than 1 , especially after 10:00 UTC. During the morning of 1 July some light rainfall took place and the measurements of the Cimel sun-photometer were resumed during the afternoon. The values of the AOD and $A E$ were still higher, around 0.6 and 1.7, respectively, indicating that the smoke still remained residually in the atmosphere. Clear skies and cirrus clouds alternated during 2 and 3 July, and only a few measurements are available, with a daily mean $A O D$ of 0.26 and 0.32 , respectively. Furthermore, the AOD slightly

\section{ACPD}

13, 22639-22685, 2013

Aerosol

microphysics and optical properties

J. L. Gómez-Amo et al.

Title Page

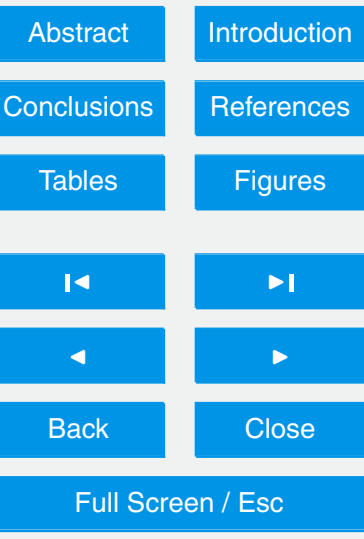

Printer-friendly Version

Interactive Discussion 
increased to 0.36 on 4 July. The AE was between 1 and 1.4, indicating that probably there was no marked change in the aerosol type during these three days.

Another interesting fact is the simultaneous presence of dust and smoke aerosols during this wildfire event, which became evident during the morning of 29 and 30 June. 5 The AOD and AE measurements showed a simultaneous decline between 08:0009:00 UTC taking values around 0.4-0.5 for the AOD, similar on both days, while AE took values around $0.3-0.5$ and $0.3-0.7$ on 29 and 30 June, respectively (Fig. 3). These lower $A E$ records are typical of large dust particles, which could be confined below the smoke layer during the whole event. Lidar measurements support this affirmation, 10 since a progressive intensification of the signal between $1.5-2 \mathrm{~km}$ altitudes was observed during the morning (until 12:00 UTC) in correspondence with the rise of AOD and $A E$ associated to the smoke load (Fig. 4b). The sudden variation in the AOD and $A E$ was related with changes in the wind direction and speed that varied the smoke load reaching Burjassot.

\section{$15 \quad 4.2$ Aerosol vertical structure and boundary layer dynamics}

The combination of lidar measurements and the modeled mixing layer height are useful to understand the aerosol vertical structure throughout the wildfire episode. For this reason, the mixing layer height determined by the HYSPLIT model is overlapped in Fig. 4. The vertical extent of the mixing layer is calculated by the model from potential 20 temperature data and finding the height of an elevated inversion at each data point. The model assumes the boundary layer depth to be equal to the height at which the potential temperature first exceeds the value at the ground by $2 \mathrm{~K}$. The temperature profile is analyzed from the top down to determine the boundary layer depth. The topdown approach reduces the influence of shallow stable layers near the ground (Draxler

\section{ACPD}

13, 22639-22685, 2013

Aerosol

microphysics and optical properties

J. L. Gómez-Amo et al.

Title Page

Abstract

Introduction

Conclusions

References

Tables

Figures

14

$>1$

4

Back

Close

Printer-friendly Version

Interactive Discussion that the interpolations between 06:00-12:00 and 18:00-00:00 UTC have the influence 
of the day/night transitions. It must be highlighted that the best values are obtained in the early afternoon, when the mixing height is fully developed (García et al., 2007).

The evolution of the aerosol vertical structure became evident throughout the day and was especially relevant during 28 June. The changes in the aerosol vertical struc5 ture may be a consequence of the stronger mixing layer dynamics during summer, which may trigger the vertical mixing in the central part of the day in coincidence with the development of the mixing layer. The mixing layer reached the maximum height $(4350 \mathrm{~m})$ for the whole period on this day, as well as the air temperature which exceeded $34^{\circ} \mathrm{C}$ shortly after noon. This behaviour was probably influenced by the Sa10 haran dust intrusion affecting the Valencia region, which showed its highest intensity on 28 June. As a consequence of the higher amplitude observed for the mixing layer, which covers the entire aerosol layer (Fig. 4a), the dust might have been embedded in a well-mixed homogeneous layer covering from the ground to $4.5 \mathrm{~km}$ altitude. When the mixing activity dropped (around 16:00 UTC), the dust layer might have been pressed towards the surface, and this may be the reason why the smoke plume seemed to be uncoupled of the lowermost aerosol layer during the late afternoon of 28 June and early morning of 29 June. This feature supports the fact that the dust particles were located below the smoke plume during the wildfire episode, and may reinforce also the explanation about the low AE values found during the morning of 29 and 30 June.

The development of the convective mixing layer and the overlying of the smoke plume appear to be coupled on 29 June, and both layers contacted around 12:00 UTC. Under regular conditions, the contact between the fully developed mixing layer and the free troposphere results in a cleaning of the lowermost atmosphere (Pahlow et al., 2005). However under these smoke conditions some ash sedimentation happened and remained till 16:00 UTC. As a result, an increase of the aerosol load is observed in the lowermost atmosphere (up to $1.2 \mathrm{~km}$ altitude) after 16:00 UTC (Fig.4b). This vertical mass exchange might vary the thermodynamic structure of the atmosphere and could explain the lifting of the smoke plume, which was lifted up around $2.5 \mathrm{~km}$ altitude after 16:00 UTC, when the mixing layer activity dropped. Similar vertical dynamics was
ACPD

13, 22639-22685, 2013

Aerosol

microphysics and optical properties

J. L. Gómez-Amo et al.

Title Page
Abstract

Conclusions

Tables

14

4

Back
Introduction

References

Figures

$\rightarrow$

$\triangleright$

Close
Full Screen / Esc

Printer-friendly Version

Interactive Discussion 
observed also on 30 June. However, in this case the intensity of the vertical mass exchange during midday was lower since the load of the smoke plume was reduced with respect to the 29 June. Nevertheless, the particle sedimentation which occurred the day before, increased the thickness of the lowest aerosol layer, and the lidar signal 5 observed in the first $500 \mathrm{~m}$ of atmosphere was more intense in comparison with that observed on 29 June.

Lower temperatures were observed from 1 to 4 July, probably due to the radiative effect induced by the smoke aerosols. The maximum temperatures on these days ranged between 22 and $25^{\circ} \mathrm{C}$ causing a weaker development of the mixing layer. An enhance10 ment of the lidar signal was observed especially on 1 July. This indicates that the number of particles near the ground became significant. Lidar signal in the lowermost atmosphere was gradually weakened until the end of the studied period.

\subsection{Surface measurements}

The vertical aerosol dynamics described in Sect. 4.2 is expected to correspond at 15 ground level. For this purpose, surface measurements of the scattering coefficient $\left(\sigma_{\mathrm{sp}}\right)$ at $550 \mathrm{~nm}$ and the scattering Ångström exponent $\left(\alpha_{\mathrm{sp}}\right)$ provided by the integrating nephelometer, with 5-min. resolution, have been analyzed throughout the studied period (Fig. 5a and b). In addition, hourly mass concentration of particulate matter $\mathrm{PM}_{2.5}$ and daily values of $\mathrm{PM}_{10}$ are also shown (Fig. 5c). PMx values have been taken at the Burjassot city monitoring station and made available by the Valencian Network of Surveillance and Control of Air Pollution (NSQAP, 2013).

No remarkable changes in the surface measurements were observed until 28 June, even when the Saharan dust intrusion was detected by column-integrated measurements on 26 June. This indicates that initially the dust layer was confined over the boundary layer and only a slight vertical mass exchange occurred since the mixing height did not exceed 1224 and $2370 \mathrm{~m}$ on 26 and 27 June, respectively. During the initial part of the studied period (24-27 June), the $\sigma_{\mathrm{sp}}$ ranged between 23 and $82 \mathrm{Mm}^{-1}$,

\section{ACPD}

13, 22639-22685, 2013

Aerosol

microphysics and optical properties

J. L. Gómez-Amo et al.

Title Page

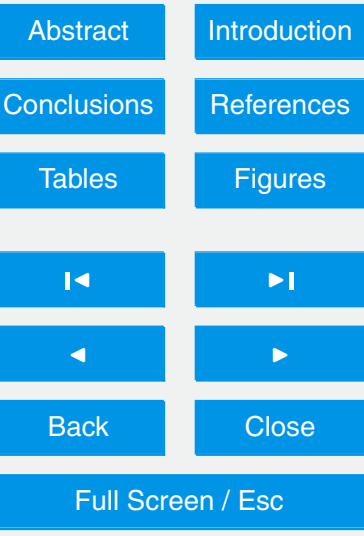

Printer-friendly Version

Interactive Discussion 
which are lower than the monthly mean for June and July (90 and $80 \mathrm{Mm}^{-1}$ respectively) at the Burjassot station reported by Esteve et al. (2012). In turn, the $\mathrm{PM}_{2.5}$ con-

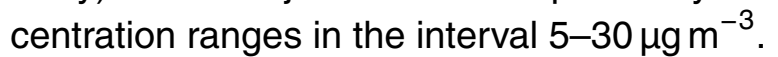

Higher values of the $\sigma_{\mathrm{sp}}$ and $\mathrm{PM}_{2.5}$ level were observed during the night of the 27528 June, with maximum values of $133 \mathrm{Mm}^{-1}$ and $38 \mathrm{\mu g} \mathrm{m}^{-3}$ respectively. $\sigma_{\mathrm{sp}}$ gradually increased on 29 and 30 June, and the absolute maximum was observed during the 1 July in coincidence with the most intense activity of the wildfire. The maximum $\sigma_{\mathrm{sp}}$ values observed during these three days were 407,589 and $2100 \mathrm{Mm}^{-1}$ respectively. Nonetheless a progressive drop is observed from 2 to 4 July, with maximum values of 1182,182 and $135 \mathrm{Mm}^{-1}$ respectively. These values indicate that a residual particle matter due to the wildfire may be remained in the atmosphere. The 24-h average values of $\sigma_{\mathrm{sp}}$ exceed the mean values reported for June-July at this station from 29 June to 2 July, and agree with them for 28 June and 3-4 July (Table 1).

$\mathrm{PM}_{2.5}$ levels followed a similar pattern to the observed for the $\sigma_{\mathrm{sp}}$ throughout the 15 studied period, despite the lower sample resolution and occasional interruption of the measurements. The main difference with the $\sigma_{\mathrm{sp}}$ lies in the $\mathrm{PM}_{2.5}$ absolute maximum being observed during the night of the 29-30 June instead of the 1 July. The particulate matter maximum was over $160 \mathrm{\mu g} \mathrm{m}^{-3}$ (Fig. 5c). The European Union (EU) legislation established a daily concentration maximum for the $\mathrm{PM}_{2.5}$ level of $25 \mathrm{\mu g} \mathrm{m}^{-3}$ (Directive 2008/50/EC) (solid red line in Fig. 5c). The 24-h averaged $\mathrm{PM}_{2.5}$ levels exceed the EU limit from 28 June to 2 July (Table 1). Therefore, both the Saharan dust particles and the wildfire smoke largely contribute to exceed the EU annual limits. Furthermore the maximum values observed for all the days within the selected temporal window overcame the EU limits.

25 A clear diurnal variability is observed for $\sigma_{\mathrm{sp}}$. Generally, the maximum values were found during the nighttime (late evening-early morning) in coincidence with the low mixing layer height. The minima were observed during the daytime (around 13 and 16:00 UTC) when the mixing layer was fully developed. This behavior is in agreement
ACPD

13, 22639-22685, 2013

Aerosol

microphysics and optical properties

J. L. Gómez-Amo et al.

Title Page

Abstract

Introduction

Conclusions

References

Tables

Figures

14

$\rightarrow 1$

4

Back

Close

Printer-friendly Version

Interactive Discussion 
with the diurnal variation of $\sigma_{\mathrm{sp}}$ during the summer season reported by Esteve et al. (2012) for the Burjassot station. In turn, the diurnal cycle for the $\mathrm{PM}_{2.5}$ level only becomes apparent during the days with the largest aerosol load, i.e. from 28 June to 2 July. For these days, a similar diurnal variability to that of $\sigma_{\mathrm{sp}}$ was observed. However, 5 for 1 July the maximum values for both $\mathrm{PM}_{2.5}$ and $\sigma_{\mathrm{sp}}$ were observed around noon. It was probably due to wet particle sedimentation caused by a light rainfall during the morning that led to the accumulation of particles near the surface.

The different diurnal evolution as well as the 1-day lag in the maximum record observed between both instruments (integrating nephelometer and PM analyzer) may 10 be mainly associated to a local source of particles due to the different air samples measured, since they are $\sim 300 \mathrm{~m}$ distant with an altitude difference around $20 \mathrm{~m}$. On the other hand, some differences related with the size of the particles at which each instrument is sensitive may arise.

Unfortunately the $\mathrm{PM}_{10}$ level measurements were not available for the whole stud15 ied period and only relative information about the large particles is available. Figure $5 \mathrm{c}$ also shows the $\mathrm{PM}_{10}$ level (black solid squares), which is sampled once a day. These observations have been assigned to the noon. $\mathrm{PM}_{10}$ levels were close to the $\mathrm{PM}_{2.5}$ levels on 27 June (before the wildfire) and 3-4 July (after the wildfire), indicating the large presence of small particles at ground level. However, a large $\mathrm{PM}_{10}$ concentration 20 of $50 \mu \mathrm{g} \mathrm{m}^{-3}$ was observed on 2 July. That record reached the $\mathrm{EU}$ limit for $\mathrm{PM}_{10}$ (Directive 1999/30/EC) (dotted red line in Fig. 5c), and that may be indicative of the possible presence of some large particles at surface level during the wildfire episode.

Qualitative information about the particle size at ground level can be obtained from $\alpha_{\mathrm{sp}}$ provided by the integrating nephelometer. Values larger than 1 were observed dur25 ing almost the whole studied period, highlighting that the amount of small particles was apparent. Nevertheless, a clear decrease in $\alpha_{\mathrm{sp}}$ was observed on 28 June in coincidence with the highest intensity of the Saharan dust intrusion. Hence the presence of large dust particle became significant also near the ground due to the intense vertical mixing occurred throughout the day. $\alpha_{\mathrm{sp}}$ increased due to the accumulation of

\section{ACPD}

13, 22639-22685, 2013

Aerosol

microphysics and optical properties

J. L. Gómez-Amo et al.

Title Page

Abstract

Introduction

Conclusions

References

Tables

Figures

14

- I

4

Back

Close
Printer-friendly Version

Interactive Discussion

Full Screen / Esc 
smoke particles produced by the wildfire, and values larger than 1.3 were observed from 29 June to 2 July at noon. On 1 July, $\alpha_{\mathrm{sp}}$ reached a value of 2.5 simultaneously to the increase of $\sigma_{\mathrm{sp}}$, indicating that the fine particles are prevalent due to the smoke presence. A marked diurnal variability of $\alpha_{\mathrm{sp}}$ was observed especially after 28 June. 5 However, it presented an opposite behavior for two different periods: 29-30 June and 1-4 July. During the first period (29-30 June), the drop of $\alpha_{\mathrm{sp}}$ was in coincidence with the raise of $\sigma_{\mathrm{sp}}$. This may be due to a combined effect of dust and a great amount of large-size ashes with short life-time in the atmosphere which were falling down during the first days of the wildfire. Conversely, a simultaneous increase of both $\sigma_{\mathrm{sp}}$ and ${ }_{10} \alpha_{\mathrm{sp}}$ was observed during the second period (1-4 July). This may be the consequence of the presence of smaller particles with longer time residence in the atmosphere. The large amount of small particles originated by the wildfire were first transported to the site, then accumulated within the atmosphere during the following days and finally remained residually in the lowermost atmosphere affecting considerably the surface 15 measurements.

\subsection{Inversion strategies and aerosol classification}

Only a few AERONET inversions were available during the 11-days window used in this work. Due to the large inhomogeneity and variability in the sky conditions caused by the presence of the smoke plume during 29 and 30 June only one AERONET inversion was 20 available during these days. Therefore the column-integrated aerosol size distribution has been alternatively obtained by means of the inversion of the spectral AOD using the King algorithm (King et al., 1978). The refractive index was considered both wavelength and size independent during the inversion procedure.

The aerosol refractive index is the most critical input parameter in order to apply 25 successfully the King inversion algorithm. Therefore the refractive index must be prescribed taking into account some independent aerosol information before the inversion procedure is applied. In this work the daily mean refractive index provided by the AERONET retrievals is used if available. However a previous aerosol classification

ACPD

13, 22639-22685, 2013

Aerosol

microphysics and optical properties

J. L. Gómez-Amo et al.

Title Page

Abstract

Introduction

Conclusions

References

Tables

Figures

14

-I

4

Back

Close
Printer-friendly Version

Interactive Discussion

Full Screen / Esc

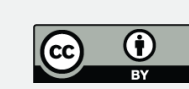


based on $A O D$ and $A E$ has been used in order to choose the aerosol refractive index when the AERONET inversions were not available (on 27, 30 June; and on 2-3 July). The aerosol evolution observed during the 11-days time window (see Sect. 4.1) allows defining four interesting situations that may be characterized with different aerosol microphysical and optical properties: (a) aerosol summer background on 24-25 June (SBG); (b) a strong dust event on 26-28 June (DDE); (c) fresh smoke episode on 29 June-1 July (FSK) and (d) residence of smoke particles on 2-4 July (RSK).

The dust cases were selected when $A O D>0.15$ and $A E<0.7$, according to the values provided by Estellés et al. (2007b) in a 4-yr climatological analysis for dust cases 10 over Valencia. The smoke cases were selected for $A O D>0.5$ and $A E>1$. Any other $A O D$ and $A E$ combinations are considered as mixed aerosol cases since they cannot be used to clearly identify the aerosol type (e.g. Pace et al., 2006). Nonetheless, differences are expected in the aerosol microphysics and optical properties for the mixed aerosol cases observed before (SBG) and after (RSK) the wildfire.

Therefore, the mean refractive index between 26 and 28 June was used for the inversions of dust cases on 27, 29 and 30 June (named as dust in Table 2). The selection of the refractive index for the smoke cases is more complicated, especially for the imaginary part since it depends on the type of burnt vegetation (i.e. its concentration of absorbing carbon) and on the aerosol aging (Stone et al., 2008; Calvo et al., 2010). No biomass burning analysis has been previously carried out in Burjassot and there are no measurements of aerosol absorption during this wildfire episode. In addition only 3 measurements of the refractive index were determined by the AERONET inversions during the FSK period, and the only observation on 29 June corresponds to a dust case, since $A E<0.7$. Therefore, the daily averaged refractive index from the AERONET inversions on 1 July was used for all the smoke cases on 28, 29 and 30 June (named as smoke in Table 2). The values of this smoke refractive index are consistent with the bibliographic values for biomass burning. The real part varies from 1.47 to 1.55 (Reid et al., 2005), while the imaginary part ranges between 0.00093 and 0.021 (e.g. Dubovik et

\section{ACPD}

13, 22639-22685, 2013

Aerosol

microphysics and optical properties

J. L. Gómez-Amo et al.

Title Page
Abstract

Conclusions

Tables

14

4

Back

\section{Introduction}

References

Figures

DI

Close
Full Screen / Esc

Printer-friendly Version

Interactive Discussion 
al., 2002). Moreover, the daily averaged refractive index from the AERONET inversions on the 4 July were used for all the mixed cases during the RSK period.

It must be pointed out that the choice of the imaginary part of the refractive index is expected to be not so critical in the retrieval of the aerosol microphysics since the 5 AOD is not sensitive to it (King et al., 1978). Conversely, the single scattering albedo and asymmetry parameter are highly sensitive to both the real and imaginary part of the refractive index (e.g. Reid et al., 2005).

\subsection{Column-integrated aerosol microphysics}

Figure 6 shows the time series of the volume concentration for the total $\left(V_{T}\right)$, fine $\left(V_{\mathrm{F}}\right)$ 10 and coarse $\left(V_{C}\right)$ particles throughout the entire period. In addition, the median radius and the standard deviation for fine $\left(\sigma_{F}\right)$ and coarse $\left(\sigma_{C}\right)$ particles as well as the fine mode fraction (FMF) and effective radius $\left(r_{\text {eff }}\right)$ are shown. The daily averaged aerosol microphysics considering the four aerosol types defined throughout the studied period are shown in Table 3. The uncertainty assigned to the averaged values represents the \pm 1 -standard deviation of the mean value.

Marked changes in the aerosol size distribution are observed due to the dust intrusion (DDE) with respect to the previous days (SBK). The dust particles contributed to modify both the fine and coarse modes. $V_{F}$ increased reaching a maximum daily average of $0.0401 \mathrm{\mu m}^{3} \mu \mathrm{m}^{-2}$ on 27 June. Moreover, $\sigma_{\mathrm{F}}$ became wider and changed 20 from $\sim 1.5$ for the SBK cases to over 1.6 for the DDE period. In addition, the fine mode was gradually shifted to larger radii and $r_{\mathrm{vF}}$ were greater than $0.12 \mu \mathrm{m}$. In turn, $V_{\mathrm{C}}$ progressively increased and the daily mean values ranged from $0.17 \mu \mathrm{m}^{3} \mu \mathrm{m}^{-2}$ to $0.32 \mu \mathrm{m}^{3} \mu \mathrm{m}^{-2}$ on 26 and 28 June respectively. Conversely, $\sigma_{\mathrm{C}}$ slightly decreased from 2 to 1.78 for the entire DDE period. As a result of these variations, a marked increase of the effective radius was observed up to a daily average maximum of $0.78 \mu \mathrm{m}$ on 28 June. The daily average effective radius for the DDE period was more than 2 times greater than the obtained for the SBK cases.
ACPD

13, 22639-22685, 2013

Aerosol

microphysics and optical properties

J. L. Gómez-Amo et al.

Title Page

Abstract

Introduction

Conclusions

References

Tables

Figures

14

$\rightarrow 1$

4

Back

Close

Printer-friendly Version

Interactive Discussion 
On the other hand, a notable variability on the aerosol size distribution is also observed during the wildfire event (FSK) for the fine and coarse modes. The load of smoke particles contributed to drastically enhance the fine mode, and $V_{\mathrm{F}}$ reached maximum values larger than $0.4 \mu^{3} \mu^{-2}$ on 29 June. This concentration exceeded consider5 ably the mean value of $0.035 \mu^{3} \mu \mathrm{m}^{-2}$ obtained in Burjassot for the summer months (Estellés et al., 2007a). $V_{C}$ gradually decreased reaching daily average values of 0.21 , 0.18 and $0.055 \mu \mathrm{m}^{3} \mu \mathrm{m}^{-2}$ on 29,30 June and 1 July respectively. However, the values remained significantly higher than those typically observed in the Burjassot station, which reached $0.04 \mu^{3} \mu^{-2}$ during the most severe dust episodes (Estellés et al., $102007 \mathrm{~b}$ ). The average value of $r_{\mathrm{vF}}$ for the FSK period was $0.134 \mu \mathrm{m}$, which is in agreement with Dubovik et al. (2002) for a more general study of biomass burning episodes in Brazil. In turn, $r_{\mathrm{vc}}$ showed large variability throughout the day with values in the range $1.8-3 \mu \mathrm{m}$. This variability was probably due to changes in the wind field that caused the interchanged presence of dust and smoke particles with different $r_{\mathrm{vc}}$. In addition, sud5 den changes in large-size ashes generated by the biomass burning, especially on 29 and 30 June, might contribute to the variability of the $r_{\mathrm{vC}}$ since they sediment faster. The size distribution changed again for the RSK period. $V_{\mathrm{F}}$ gradually decreased from 0.069 to $0.035 \mu \mathrm{m}^{3} \mu \mathrm{m}^{-2}$ from 1 to 4 July. Conversely, a slight increase of $V_{C}$ was observed with an average value of $0.092 \mu \mathrm{m}^{3} \mu \mathrm{m}^{-2}$ during the RSK cases. This would 20 indicate that the fine smoke particles were gradually removed from the atmosphere and remained residually several days after the wildfire started.

The dust cases show a noticeable influence on the coarse particles, and consequently the FMF represented on average only the $12 \%$ of the total volume (Table 3 ). This was related with the low values of AE observed for the DDE cases. On the contrary, the FMF was higher for the other three aerosol types and took similar values around $30 \%$ for the SBG and RSK periods respectively. For the smoke cases, the FMF increased up to $50 \%$ on average. It should be pointed out that smoke aerosols contribute mainly to the fine mode (e.g. Reid et al., 2005). In turn, the coarse mode may be more influenced by the background situation of the studied region during the wildfire

\section{ACPD}

13, 22639-22685, 2013

Aerosol

microphysics and optical properties

J. L. Gómez-Amo et al.

Title Page

Abstract

Introduction

Conclusions

References

Tables

Figures

14

$\rightarrow 1$

4

Back

Close

Printer-friendly Version

Interactive Discussion 
event; and different growing and mixture mechanisms may also vary its relevance. The hygroscopic growth may take an important role in the Amazonian region where a large amount of water vapour is expected within the atmosphere and may explain the larger $r_{\mathrm{vc}}$ values obtained by Dubovik et al. (2002). On the other hand, the coarse mode may 5 not be so relevant in urban environments (e.g. Chubarova et al., 2012) or in rural areas (e.g. Calvo et al., 2010). However as discussed in Sect. 4.1, the simultaneous presence of dust and smoke particles was observed during several days throughout the studied period, and that is why the coarse mode contribution remained also relevant during the FSK period.

10 In order to address the large variability observed in the aerosol microphysics which is sensitive to the aerosol type, the daily averaged aerosol size distributions for the four aerosol types defined throughout the studied period are shown in Fig. 7. The most interesting aspects are associated to the simultaneous presence of dust and smoke particles, which lead to large variability in the aerosol size distribution during 15 the DDE and FSK periods (Fig. 7b and c). This variability is mainly related to changes in the volume concentration of the fine and coarse modes. A second order variability is associated to the radius and standard deviation of both modes.

The fine mode remained similar for all the DDE cases, except on 28 June when the highest load of dust particles was observed. This caused some widening in the fine mode which was also shifted to larger radii. A noticeable contribution of the dust particles to the coarse mode was also observed. This contribution increased the volume concentration between 26 and 28 June, as it was expected from the increase of the AOD and the corresponding decrease of the AE during these days (Fig. 3). $V_{C}$ gradually decreased in the dust cases observed during the FSK period (29 and 30 June). These observations were early in the morning (between 08:00-09:00 UTC), when changes in the wind field around $2 \mathrm{~km}$ altitude removed the smoke plume that was placed around 2-km altitude (Fig. 4). In turn, the dust particles were placed in the boundary layer, as discussed in Sect. 4.2. Because of the totally uncoupling of both aerosol layers, no mixing between dust and smoke took place during the morning. This

\section{ACPD}

13, 22639-22685, 2013

Aerosol

microphysics and optical properties

J. L. Gómez-Amo et al.

Title Page
Abstract

Conclusions

Tables

14

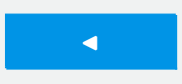

Back

\section{Introduction}

References

Figures

$\rightarrow 1$

$>$

Close
Full Screen / Esc

Printer-friendly Version

Interactive Discussion 
explains that no marked variations in the fine mode were caused by smoke particles in the dust cases. Therefore the radius shift observed on 28 June for the fine mode looks related to the dust interaction with the background aerosol in a well-mixed boundary layer due to the great convective activity aforementioned (Sect. 4.2). The values of $V_{C}$ 5 exceed the typical values obtained under African episodes by an average factor of 3.4. The values displayed for the rest of the size parameters are in agreement with those reported by Estellés et al. (2007b) for African air masses at Burjassot since these parameters depend mainly on the dust origin.

Notable differences were observed in the day-by-day aerosol size distributions for 10 the smoke cases (Fig. 7c). The arrival of the fresh smoke caused the increase of $V_{F}$ and $V_{C}$ by a factor of 3 and 2 respectively with respect to the dust cases, on 28 June. The contribution of smoke particles to the fine mode was extremely enhanced on 29 June, and $V_{\mathrm{F}}$ was more than 10 times the value observed for the dust cases. $V_{\mathrm{F}}$ on 30 June and 1 July decreased by $1 / 3$ and $1 / 6$ of the maximum value observed on 29 June.

$15 r_{\mathrm{vF}}$ was smaller than the observed for the dust cases and remained similar between 28 and 30 June, and slightly decreased on 1 July.

The $r_{\mathrm{vc}}$ obtained for the smoke cases display similar values to those observed for the dust cases on 28 June. This indicates that the smoke particles contributed to enhance the volume concentration without changing the radius. In turn, the coarse mode for the smoke cases decreased on 29-30 June and was similar both in volume and radius to that observed for the dust cases on 29-30 June. This suggests that no variation on the aerosol type was observed for the coarse mode between 29 and 30 June. Conversely, differences in the $r_{\mathrm{vC}}$ appeared between 28 and 29-30 June, shifting to larger radii. In addition, no remarkable $r_{\mathrm{vc}}$ dependence with the considered aerosol type (dust or smoke) was observed for a fixed day. This may suggest that the lingering high load of large-size ashes that continuously fell down in this region since the wildfire started (the night on 28 June) may result in the observed shift in the coarse mode to larger radii on 29 and 30 June.

\section{ACPD}

13, 22639-22685, 2013

Aerosol

microphysics and optical properties

J. L. Gómez-Amo et al.

Title Page
Abstract

Conclusions

Tables

14

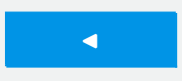

Back
Introduction

References

Figures

$\rightarrow 1$

Close
Full Screen / Esc

Printer-friendly Version

Interactive Discussion 
The size distributions observed for the FSK and RSK periods are somewhat similar. The main differences were found in the volume concentration of the fine and coarse modes, which was enhanced by a factor of 2 during the RSK period. Moreover, a slight shift to larger radii for the RSK cases is observed, especially for the fine mode.

\section{$5 \quad 4.6$ Column-integrated aerosol optical properties}

The aerosol microphysical parameters retrieved by the King algorithm have been used as an input in a forward run of an implementation of the Mie theory to obtain the single scattering albedo (SSA) and the asymmetry parameter $(g)$ at four AERONET operative wavelengths $(440,675,870$ and $1020 \mathrm{~nm})$. The spectral variation of the refractive index has been taken into account for the retrieval of these aerosol optical properties.

The SSA and $g$ obtained using the proposed approach have been compared against the 38 AERONET inversions available for the entire temporal window of this study. This comparison has been carried out by means of a linear regression between the values obtained with our methodology and those of AERONET for each wavelength. The 5 root mean square deviation (RMSD) has been also taken into account. A high level of agreement for all wavelengths is found, and the correlation coefficients are higher than 0.97 and 0.98 for the SSA and grespectively. Moreover, the RMSD is within the ranges $(0.03-0.04 \%)$ and $(0.02-0.05 \%)$ for the SSA and $g$ respectively. These RMSD also account for the instantaneous variations of the refractive index during a day since our retrieval used the same refractive index (daily average) for the whole day and it was only varied if a different aerosol type was well identified. The agreement with the AERONET inversions provides confidence in our retrieval, which not being perfect at least is plausible, and permits the use of our results in order to study the aerosol optical properties throughout the studied period. These results are in agreement with those

obtained by other similar approaches that imply assumptions in the values of the refractive index (e.g. Gónzalez-Jorge and Ogren, 1996; Andrews et al., 2006; Kassianov et al., 2005 and 2007).
ACPD

13, 22639-22685, 2013

Aerosol

microphysics and optical properties

J. L. Gómez-Amo et al.

Title Page

Abstract

Introduction

Conclusions

References

Tables

Figures

14

$\rightarrow 1$

4

Back

Close

Printer-friendly Version

Interactive Discussion 
Figure 8 shows the spectral dependence of the daily averaged SSA and $g$ according to the different aerosol types found during the studied temporal window. It should be highlighted that both parameters are highly sensitive to the aerosol size distribution as well as to both the real and imaginary parts of the refractive index (e.g. Kassianov et al., 5 2005). However, several aspects should be pointed out depending on the aerosol type since the refractive index was prescribed in the retrieval of aerosol optical properties. Our implementation of the Mie algorithm was run using the same refractive index for all observations identified as smoke and the daily average from the AERONET inversions for 1 July was used. The same was done for the residual smoke observations but 10 using the daily average from the AERONET inversions for 4 July. As a result of these assumptions, the day-to-day variability of the aerosol optical properties for both cases ( smoke and residual smoke) cannot be due to variations in the refractive index, but to differences in the retrieved aerosol size distributions. On the contrary, the refractive index is changed for the observations identified as dust depending on the day, as was explained in Sect. 4.3. The same criterion was used for the summer background cases. This implies that changes in the aerosol size distribution as well as in the refractive index are involved in the day-to-day variability observed in the aerosol optical properties for the summer background and dust cases.

Moderate to large absorption for the SBG cases is observed, although differences 20 are observed for the SSA. The aerosol size distribution is similar on 24 and 25 June (Fig.7a). Hence the SSA variation during these two days is only due to the larger imaginary part of the refractive index obtained on 25 June, while the real part remains similar between them. Different spectral behaviour for the SSA was observed for 24 and 25 June, which varied within the ranges $(0.87-0.90)$ and $(0.80-0.83)$ at 440 and $870 \mathrm{~nm}$ respectively. This high absorption may be a consequence of the prevalent urban and industrial pollution affecting the Burjassot station due to its closeness to the Valencia metropolitan area (Estellés et al., 2007a: Esteve et al., 2012). The asymmetry parameter presents low variability during these days due to a similar aerosol size distribution, and ranges from a maximum of 0.63 at $440 \mathrm{~nm}$ to a minimum of 0.53 at 675 or $870 \mathrm{~nm}$

\section{ACPD}

13, 22639-22685, 2013

Aerosol

microphysics and optical properties

J. L. Gómez-Amo et al.

Title Page

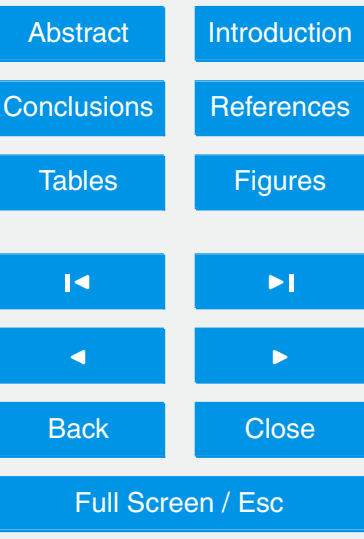

Printer-friendly Version

Interactive Discussion 
depending on the considered day (Fig. 8e). Both SSA andgvalues were within the values obtained by inversion of sky radiances for the summer period (Estellés et al. 2007a).

During the RSK period, the spectral variation of SSA and $g$ is somehow similar to 5 the values of the SBG cases. Nonetheless, the RSK aerosols appear slightly less absorbent due to the smaller values of the imaginary part of the refractive index than those of the SBG cases. This similarity is also observed for $g$ in the comparison between SBG and RSK cases. This behaviour is a consequence of the similar aerosol size distribution for the SBG and RSK periods, especially for the retrieved median radii and 10 standard deviations. This seems to indicate that both situations contained the same aerosol type, and the most noticeable difference was due to the amount of particles which was increased during the RSK period due to the wildfire episode.

The SSA for all the dust cases display lower values at $440 \mathrm{~nm}$, between 0.87 and 0.91 , and relatively constant spectral behaviour between $675-1020 \mathrm{~nm}$, ranging from 150.94 to 0.98 depending on the different cases (Fig.8b). This typical spectral dependency for dust particles is due to the larger imaginary part of the refractive index at $440 \mathrm{~nm}$ and relatively constant values in the wavelength range 675-1020 nm (e.g. Dubovik et al., 2002). The SSA values for 27, 29 and 30 June show small differences because the same refractive index was used for these cases, even if the volume concentration changed substantially among these cases. Conversely, the SSA values between the 26 and 28 June at longer wavelengths differed noticeable. This is associated to the higher absorption observed on 26 June since the imaginary part of the refractive index doubled the values for 28 June. In addition, the differences in the imaginary part of the refractive index are coupled with a large enhancement of $V_{C}$, which noticeably increased the scattering on 28 June, resulting in higher SSA values at longer wavelengths.

The spectral variation of $g$ is similar for all dust cases, despite of the differences in the refractive index (Fig. 8f). The maximum values are observed at $440 \mathrm{~nm}$ and are larger than 0.70 . In turn, the minima are observed at $675-870 \mathrm{~nm}$ and fall in the range

\section{ACPD}

13, 22639-22685, 2013

Aerosol

microphysics and optical properties

J. L. Gómez-Amo et al.

Title Page

\section{Abstract}

Introduction

Conclusions

References

Tables

Figures

14

$\rightarrow$

4

Back

\section{Full Screen / Esc}

Printer-friendly Version

Interactive Discussion 
$0.66-0.75$. This suggests a large forward scattering in the whole spectral range which is higher as $V_{C}$ increases.

On the contrary, the wavelength dependence of SSA and gis more variable among the smoke cases than for the dust ones (Fig. 8c, g). This variability is due to important 5 differences in the aerosol size distribution. Slight spectral variation is observed for the SSA when smoke and dust particles are simultaneously present during 28 and 29 June. However, the absorption shown for both days is really different due to the opposite weight of the fine and coarse mode. High absorption is observed on 28 June, with the SSA showing values smaller than 0.82 for the entire spectral range. On the contrary, 10 the SSA for 29 June is higher than 0.95 for all wavelengths and is somehow similar to that observed for the dust cases at wavelengths over $675 \mathrm{~nm}$. Moreover, the SSA at $440 \mathrm{~nm}$ is also increased. The SSA differences observed between 28 and 29 June highlight the relevance of the coarse mode, which is responsible of the flat spectral response at longer wavelengths. In turn, the extremely high aerosol load on 29 June due to the contribution of fine mode smoke particles strongly increased the scattering fraction resulting in a marked rise of the SSA. On the other hand, the decrease of the SSA with the wavelength observed on 30 June and 1 July corresponds to the typical spectral dependence observed during biomass burning episodes around the world (e.g. Dubovik et al., 2002; Eck et al., 2009 and Chubarova et al., 2012). For these cases, the SSA ranged from $0.88-0.91$ at $440 \mathrm{~nm}$ to 0.83 at $1020 \mathrm{~nm}$.

The imaginary part of the refractive index for the smoke cases is relatively constant with the wavelength (Table 2). As a result, the aerosol size distribution modulates the spectral variation of the aerosol absorption. Therefore, its wavelength dependence is reduced in cases with extremely high aerosol load $(A O D>2)$ such as the observed on 28 and 29 June. Moreover, the aerosol absorption is higher when the contribution of the coarse particles increased, This effect may be accounted for by means of the changes observed in the $r_{\text {eff }}$ and FMF. In fact, the $r_{\text {eff }}$ decreases from 0.65 to 0.25 , while the FMF increases for the smoke cases on 28 and 29 June respectively. Therefore, the contribution of the absorption cross section to the total extinction at larger radii

\section{ACPD}

13, 22639-22685, 2013

Aerosol

microphysics and optical properties

J. L. Gómez-Amo et al.

Title Page

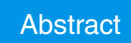

Introduction

Conclusions

References

Tables

Figures

14

- I

4

Back

Close
Printer-friendly Version

Interactive Discussion

Full Screen / Esc

Discusion 
increases with $r_{\text {eff }}$. Conversely, the spectral variation of the absorption typical of the smoke aerosols, was observed in cases with moderately-high and low aerosol load $(A O D<1.5)$ with high FMF.

The asymmetry parameter observed for the smoke cases on 28 June is similar to that 5 obtained for the dust cases since a high load of coarse particles favours the forward scattering. Hence $g$ remains over 0.68 for all wavelengths and shows small spectral dependence. The large contribution of the fine mode to the total volume induces great $g$ wavelength dependence, typical of the smoke aerosols, which drops down with wavelength and limits the forward scattering. In those cases, $g$ ranges from $0.63-0.68$ at

$10440 \mathrm{~nm}$, reaching a minimum of 0.55 at $1020 \mathrm{~nm}$ when the highest FMF is observed on 29 June.

It should be pointed out that the size distribution for the smoke cases on the 28 June may be composed by a fine mode of smoke particles and a coarse mode of dust particles. However, the aerosol optical properties have been obtained using the refractive index defined for the smoke cases which implies higher real part and different spectral dependency for the imaginary part. Therefore part of the differences observed in the aerosol optical properties with respect to the other smoke cases may be due to the selection of refractive index in the Mie computations.

\section{Conclusions}

20 An intense wildfire event which took place in Valencia (Eastern Spain) during summer 2012 has been analysed. The most intensive activity of the wildfire was during 29-30 June, and a 11-days temporal window (24 June-4 July) was selected for the study of the column-integrated aerosol microphysics and optical properties at Burjassot station. In addition, the aerosol vertical structure and its relationship with the aerosol properties at ground level have been also analysed.

AOD at $500 \mathrm{~nm}$ remained larger than 2 during the most intense period of the wildfire event, and reached an extremely unusual maximum of 8 on 29 June. AE values
ACPD

13, 22639-22685, 2013

Aerosol

microphysics and optical properties

J. L. Gómez-Amo et al.

Title Page

Abstract

Introduction

Conclusions

References

Tables

Figures

14

- I

4

Back

Close

Printer-friendly Version

Interactive Discussion 
increased up to 2.2 due to the smoke particles. The variability of AOD and AE allowed to define four interesting aerosol situations during the studied period: (a) aerosol summer background (24-25 June); (b) a strong dust event (26-28 June); (c) fresh smoke episode (29 June-1 July); and (d) residual subsidence of smoke particles (2-4 July). 5 The column-integrated aerosol microphysical parameters were obtained by means of the inversion of spectral AOD using the King method. In addition, the optical properties (SSA and $g$ ) were determined from the combination of the aerosol size distribution and the Mie theory. The results highlight the differences in the aerosol microphysical and optical properties among the identified periods.

10 The smoke particles drastically enhanced the volume concentration of the fine mode with a maximum of $0.4 \mu \mathrm{m}^{3} \mu \mathrm{m}^{-2}$, which is 10 times higher than the summer background. Lidar vertical profiles allowed confirming that the smoke plume was initially found over the dust layer. Dust particles were characterized by a large contribution of the coarse mode concentration. Therefore, the coarse mode appeared also significant during the most intense period of the wildfire episode. As a result, the aerosol optical properties obtained during the smoke cases display high variability which was modulated by the volume of coarse particles.

Similar aerosol microphysical and optical properties were observed before and after the event. Nonetheless the smoke highly contributed to increase the amount of particles remaining in the atmosphere after the event, especially in the fine mode.

The extraordinary high load of smoke particles together with a strong dust event, combined with the intense convective activity of the mixing layer, resulted in a dramatic increase of the scattering coefficient and the particle matter levels at ground level. The impact at surface level showed a 1-day lag compared with the column-integrated measurements. The scattering coefficient and the $\mathrm{PM}_{2.5}$ levels displayed extremely high maximum values of $2100 \mathrm{Mm}^{-1}$ and $160 \mathrm{\mu g} \mathrm{m}^{-3}$, respectively. These records exceed by a factor of 26 and 7 the monthly averages for June and July. Furthermore, the Saharan dust particles and the wildfire smoke largely contributed to exceed the EU particle matter annual limits.

\section{ACPD}

13, 22639-22685, 2013

Aerosol

microphysics and optical properties

J. L. Gómez-Amo et al.

Title Page

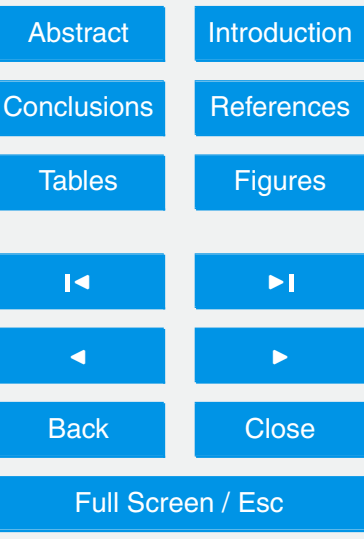

Printer-friendly Version

Interactive Discussion 
Acknowledgements. This work was supported jointly by the Spanish Ministry of Economy and Competitiveness and the European Regional Development Fund through projects CGL201124290 and CGL2012-33294, and by the Valencia Autonomous Government through project PROMETEO/2010/064. J. L. Gómez-Amo held a postdoctoral fellowship of Spanish Ministry of

5 Education (EX2010-1192). A. R. Esteve held a postdoctoral fellowship of the VALi+d program by the Valencia Autonomous Government (APOSTD/2012/078). C. Marcos was supported by PROMETEO Cl10-196 from the Valencia Autonomous Government. S. Segura and V. Estellés held the fellowships BES-2010-031626 and JCI-2009-04455, respectively. MSG/SEVIRI Level1 data provided by Eumetsat/Eumetcast/LOA. We thank the ICARE Data and Services Center

\section{References}

Amiridis, A., Balis, D., Giannakaki, E., Kazadzis, S., Arola, A., and Gerasopoulos, E.: Characterization of the aerosol type using simultaneous measurements of the lidar ratio and estimations of the single scattering albedo, Atmos. Res. 101, 46-53, doi:10.1016/j.atmosres.2011.01.010, 2011.

Anderson, T. L. and Ogren J. A.: Determining aerosol radiative properties using the TSI 3563 integrating nephelometer, Aerosol Sci. Technol., 29, 57-69, 1998.

Anderson, T. L., Covert, D. S., Marshall, S. F., Laucks, M. L., Charlson, R. J., Waggoner, A. P., Ogren, J. A., Caldow, R., Holm, R. L., Quant, F. R., Sem, G. J., Wiedensohler, A., Ahlquist, N. A., and T. S. Bates, Performance characteristics of a high-sensitivity, three-wavelength, total scatter/backscatter nephelometer, J. Atmos. Ocean. Technol., 13, 967-986, 1996.

Andreae, M. O. and Crutzen, P. J.: Atmospheric Aerosols: Biogeochemical Sources and Role in Atmospheric Chemistry, Science 276, 1052-1058, 1997.

Andreae, M. O., Fishman, J., and Lindesay, J.: The Southern Tropical Atlantic Region Experiment (STARE): Transport and atmospheric chemistry near the Equator-Atlantic (TRACE-A) and Southern Africa fire/atmosphere research initiative (SAFARI): an introduction, J. Geophys. Res., 101, 23519-23520, 1996.

Andreae, M. O., Rosenfeld, D., Artaxo, P., Costa, A. A., Frank, G. P., Longo, K. M., and SilvaDias, M. A. F.: Smoking Rain Clouds over the Amazon, Science, 303, 1337-1342, 2004

\section{ACPD}

13, 22639-22685, 2013

Aerosol

microphysics and optical properties

J. L. Gómez-Amo et al.

Title Page

Abstract

Introduction

Conclusions

References

Tables

Figures

14

$\rightarrow 1$

4

Back

Close

Full Screen / Esc

Printer-friendly Version

Interactive Discussion 
Andrews, E., Sheridan, P. J., Fiebig, M., McComiskey, A., Ogren, J. A., Arnott, P., Covert, D., Elleman, R., Gasparini, R., Collins, D., Jonsson, H., Schmid, B., and Wang, J.: Comparison of methods for deriving aerosol asymmetry parameter, J. Geophys. Res., 111, D05S04, doi:10.1029/2004JD005734, 2006.

5 Balis, D. S., Amiridis, V., Zerefos, C., Gerasopoulos, E., Andreae, M., Zanis, P., Kazantzidis, A., Kazadzis, S. and Papayannis, A. Raman lidar and sunphotometric measurements of aerosol optical properties over Thessaloniki, Greece during a biomass burning episode, Atmos. Environ., 37, 4529-4538, 2003.

Berkoff, T. A., Welton, J. E. J., Campbell, R., Scott, V. S., and Spinhirne, J. D.: Investigation of overlap correction techniques for the Micro-Pulse LidarNETwork (MPLNET). In: Proc. Geoscience and Remote Sensing Symp. 2003, IGARSS'03, Toulouse, France, IEEE International, 7, 4395-4397, doi:10.1109/IGARSS.2003.1295527, 2003.

Bruegge, C. J., Conel, J. E., Green, R. O., Margolis, J. S. Holm, R. G., and Toon, G.: Water vapor abundance retrievals during FIFE, J. Geophys. Res., 97, 18759-18768, 1992.

Calvo, A. I., Pont, V., Castro, A., Mallet, M., Palencia, C., Roger, J. C., Dubuisson, P., and Fraile, R.: Radiative forcing of haze during a forest fire in Spain, J. Geophys. Res., 115, D08206, doi:10.1029/2009JD012172, 2010.

Campanelli, M., Estelles, V., Smyth, T., Tomasi, C., Martínez-Lozano, M. P., Claxton, B., Muller, P., Pappalardo, G.,Pietruczuk, A., Shanklin, J., Colwell, S., Wrench, C., Lupi, A.,Mazzola, M., Lanconelli, C., Vitale, V., Congeduti, F., Dionisi, D., Cardillo, F., Cacciani, M., Casasanta, G., and Nakajima, T.: Monitoring of Eyjafjallajökull volcanic aerosol by the new Euro-pean Skynet Radiometers (ESR) network, Atmos. Environ., 48, 33-45, doi:10.1016/j.atmosenv.2011.09.070, 2012

Chubarova, N., Nezval, Ye., Sviridenkov, I., Smirnov, A., and Slutsker, I.: Smoke aerosol and its radiative effects during extreme fire event over Central Russia in summer 2010, Atmos. Meas. Tech., 5, 557-568, doi:10.5194/amt-5-557-2012, 2012.

Diner, D. J., Beckert, J. C., Bothwell, G. W., and Rodriguez, J. I.: Performance of the MISR instrument during its first 20 months in Earth orbit, IEEE Trans. Geosci. Remote Sens., 40, 1449-1466, 2002.

30 Directive 1999/30/CE of the European Parliament and of the Council of 22 April 1999 on ambient air quality and cleaner air for Europe, 1999.

Directive 2008/50/EC of the European Parliament and of the Council of 21 May 2008 on ambient air quality and cleaner air for Europe, 2008.

Aerosol

microphysics and optical properties

J. L. Gómez-Amo et al.

Title Page

Abstract

Introduction

Conclusions

References

Tables

Figures

14

$\rightarrow 1$

4

Back

Close

Full Screen / Esc

Printer-friendly Version

Interactive Discussion

\section{9}


Draxler, R. R. and Hess, G. D.: An overview of the HYSPLIT_4 modeling system for trajectories, dispersion, and deposition. Austral. Meteorol. Mag., 47, 295-308, 1998.

Draxler, R. R. and Rolph, G. D.: HYSPLIT (HYbrid Single-Particle Lagrangian Integrated Trajectory) Model access via NOAA ARL READY Website http://ready.arl.noaa.gov/HYSPLIT.php, NOAA Air Resources Laboratory, Silver Spring, MD, USA, 2013.

Dubovik, O., Holben, B., Eck, T. F., Smirnov, A., Kaufman, Y. J., King, M. D., Tanré, D., and Slutsker, I.: Variability of absorption and optical properties of key aerosol types observed in worldwide locations, J. Atmos. Sci., 59, 590-608, 2002.

Eck, T. F., Holben, B. N., Ward, D. E., Dubovik, O., Reid, J. S., Smirnov, A., Mukelabai, M. M., Hsu, N. C., O'Neill, N. T., and Slutsker, I.: Characterization of the Optical Properties of Biomass Burning Aerosols in Zambia during the 1997 ZIBBEE experiment, J. Geophys. Res., 106, 3425-3448, 2001.

Eck, T. F., Holben, B. N., Reid, J. S., Sinyuk, A., Hyer, E. J., O’Neill, N. T., Shaw, G. E., Vande Castle, J. R., Chapin, F. S., Dubovik, O., Smirnov, A., Vermote, E., Schafer, J. S., Giles, D., Slutsker, I., Sorokine, M., and Newcomb, W. W.: Optical properties of boreal region biomass burning aerosols in central Alaska and seasonal variation of aerosol optical depth at an Arctic coastal site, J. Geophys. Res., 114, D11201, doi:10.1029/2008JD010870, 2009.

Estellés, V., Utrillas, M. P., Martínez-Lozano, J. A., Alcántara, A., Alados-Arboledas, L., Olmo, F. J., Lorente, J., de Cabo, X., Cachorro, V., Horvath, H., Labajo, A., Sorribas, M., Díaz, J. P., Díaz, A. M., Silva, A. M., Elías, T., Pujadas, M., Rodrigues, J. A., Cañada, J., and García, Y.: Intercomparison of spectroradiometersans Sun photometers for the determination of the aerosol optical depth during the VELETA-2002 field campaign, J. Geophys. Res., 111, D17207, doi:10.1029/2005JD006047, 2006.

Estellés, V., Martínez-Lozano, J. A., Utrillas, M. P., and Campanelli, M., Columnar aerosol properties in Valencia (Spain) by ground-based Sun photometry, J. Geophys. Res., 112, D11201, doi:10.1029/2006JD008167, 2007a.

Estellés, V., Martínez-Lozano, J. A., and Utrillas, M. P.: Influence of air mass history on the columnar aerosol properties at Valencia, Spain, J. Geophys. Res., 112, D15211, doi:10.1029/2007JD008593, 2007b.

30 Estellés, V., Campanelli, M., Smyth, T. J., Utrillas, M. P., and Martínez-Lozano, J. A.: AERONET and ESR sun direct products comparison performed on Cimel CE318 and Prede POM01 solar radiometers, Atmos. Chem. Phys., 12, 11619-11630, doi:10.5194/acp-12-11619-2012, 2012.

ACPD

13, 22639-22685, 2013

Aerosol

microphysics and optical properties

J. L. Gómez-Amo et al.

Title Page

Abstract

Introduction

Conclusions

References

Tables

Figures

14

$>1$

4

Back

$\checkmark$

Close

Printer-friendly Version

Interactive Discussion 
Esteve, A. R., Estellés, V., Utrillas, M. P. and Martínez-Lozano, J. A.: In-situ integrating nephelometer measurements of the scattering properties of atmospheric aerosols at an urban coastal site in western Mediterranean, Atmos. Environ.,47, 43-50, 2012.

Feingold, G., Remer, L. A., Ramaprasad, J., and Kaufman, Y. J.: Analysis of smoke impact on clouds in Brazilian biomass burning regions: An extension of Twomey's approach. J. Geophys. Res. 106, 22907-22922, 2001

Fernald, F.: Analysis of atmospheric lidar observations: some comments, Appl. Optics, 23, 652653, 1984.

Formenti, P., Elbert, W., Maenhaut, W., Haywood, J., and Andreae, M. O.: Chemical compositionof mineral dust aerosol during the Saharan Dust Experiment (SHADE) airbornecampaign in the Cape Verde region, September 2000, J. Geophys. Res., 108, 8576, doi:10.1029/2002jd002648, 2003.

García, M. A., Sánchez, M. L., de Torre, B., and Pérez, I. A.: Characterization of the mixing height temporal evolution by means of a laser dial system in an urban area-intercomparison results with a model application, Ann. Geophys., 25, 2119-2124, doi:10.5194/angeo-252119-2007, 2007.

Gaudichet, A., Echalar, F., Chatenet, B., Quisefit, J. P., Malingre, G., Cachier, H., Buat-Menard, P., Artaxo, P., and W. Maenhaut, Trace elements in tropical African savanna biomass burning aerosols, J. Atmos. Chem., 22, 19-39, 1995.

20 Gonzalez-Jorge, H. and Ogren, J. A.: Sensitivity of retrieval aerosol properties to assumptions in the inversion of spectral optics depths, J. Atm. Sci., 53, 3669-3683, 1996.

Heintzenberg, J. and Charlson, R. J.: Design and applications of the integrating nephelometer: A review, J. Atmos. Ocean. Technol., 13, 987-1000, 1996.

Hobbs, P. V., Reid, J. S., Herring, J. A., Nance, J. D., Weiss, R. E., Ross, J. L., Hegg, D. A., Ottmar, R. D., and Liousse, C.: Particle and trace gas measurements in the smoke from prescribed burns of forest products in the Pacific Northwest, edited by: Levine, J. S., Biomass Burning and Global Change, MIT Press, Cambridge, MA, 697-715, 1996.

Holben, B. N. , Eck, T. F. Slutsker, I. , Tanré, D., Buis, J. P., Setzer, A., Vermote, E., Reagan, J. A., Kaufman, Y. J., Nakajima, T., Lavenu, F., Jankowiak, I., and Smirnov, A.: AERONET - A federated instrument network and data archive for aerosol characterization, Remote Sens. Environ., 66, 1-16, 1998.

NSQAP, http://www.cth.gva.es/cidam/emedio/atmosfera (last access: April 2013), 2013.

\section{ACPD}

13, 22639-22685, 2013

Aerosol

microphysics and optical properties

J. L. Gómez-Amo et al.

Title Page

Abstract

Introduction

Conclusions

References

Tables

Figures

14

$>1$

4

Back

$>$

Close

Full Screen / Esc

Printer-friendly Version

Interactive Discussion 
Hungershoefer, K., Zeromskiene, K., linuma, Y., Helas, G., Trentmann, J., Trautmann, T., Parmar, R. S., Wiedensohler, A., Andreae, M. O., and Schmid, O.: Modelling the optical properties of fresh biomass burning aerosol produced in a smoke chamber: results from the EFEU campaign, Atmos. Chem. Phys., 8, 3427-3439, doi:10.5194/acp-8-3427-2008, 2008.

5 Kahn, R., Chen, Y., Nelson, D. L., Leung, F.-Y., Li, Q., Diner, D. J., and Logan, J. A.: Wildfire smoke injection heights - Two perspectives from space, Geophys. Res. Lett. 35, L04809, doi:10.1029/2007GL032165, 2008.

Kassianov, E. I., Flynn, C. J., Ackerman, T. P., and Barnard, J. C.: Aerosol single-scattering albedo and asymmetry parameter from MFRSR observations during the ARM Aerosol IOP 2003, Atmos. Chem. Phys., 7, 3341-3351, doi:10.5194/acp-7-3341-2007, 2007.

Kassianov, E. I., Barnard, J. C., and Ackerman, T. P.: Retrieval of aerosol microphysical properties using surface MultiFilter Rotating Shadowband Radiometer (MFRSR) data: Modeling and observations, J. Geophys. Res., 110, D09201, doi:10.1029/2004JD005337, 2005.

Kaufman, Y. J., Hobbs, P. V., Kirchhoff, V. W. J. H., Artaxo, P., Remer, L. A., Holben, B. N., King,

15 M. D., Ward, D. E., Prins, E. M., Longo, K. M., Mattos, L. F., Nobre, C. A., Spinhirne, J. D., Ji, Q., Thompson, A. M., Gleason, J.F., Christopher, S. A., and Tsay, S. C.: Smoke, Clouds, and Radiation-Brazil (SCAR-B) experiment, J. Geophys. Res., 103, 31783-31808, 1998.

King, M., Byrne, D., Herman, B., and Reagan, J.: Aerosol size distributions obtained by inversion of spectral optical depth measurements, J. Atmos. Sci., 35, 2153-2167, 1978.

20 Kivekäs, N., Kerminen, V. M., Anttila, T., Korhonen, H., Lihavainen, H., Komppula, M., and Kulmala, M.: Parameterization of cloud droplet activation using a simplified treatment of the aerosol number size distribution, J. Geophys. Res., 113, D15207, doi:10.1029/2007JD009485, 2008.

Klett, J. D.: Lidar inversion with variable backscatter/extinction ratios.Appl. Opt., 24, 1638-1643, 1985.

Laden, F., Neas, L. M., Dockery, D. W., and Goldammer, J. G.: Association of fine particles matter from different sources with daily mortality in six US cities, Environ. Health Perspect., 108, 941-947, 2000.

Liu, Y., Kahn, R. A., Chaloulakou, A., and Koutrakis, P.: Analysis of the impact of the forest fires in August 2007 on air quality of Athens using multi-sensor aerosol remote sensing data, meteorology and surface observations, Atmos. Environ., 43, 3310-3318. Doi:10.1016/j.atmosenv.2009.04.010, 2009.
ACPD

13, 22639-22685, 2013

Aerosol

microphysics and optical properties

J. L. Gómez-Amo et al.

Title Page

Abstract

Introduction

Conclusions

References

Tables

Figures

14

$\rightarrow 1$

4

Back

Close

Full Screen / Esc

Printer-friendly Version

Interactive Discussion 
Luderer, G., Trentmann, J., Winterrath, T., Textor, C., Herzog, M., Graf, H. F., and Andreae, M. O.: Modeling of biomass smoke injection into the lower stratosphere by a large forest fire (Part II): sensitivity studies, Atmos. Chem. Phys., 6, 5261-5277, doi:10.5194/acp-6-52612006, 2006.

5 Mariano, G. L., Lopes, F. J. S., Jorge, M., and Landulfo, E.: Assessment of biomass burnings activity with the synergy of sunphotometric and LIDAR measurements in Sao Paulo, Brazil. Atmos. Res., 98, 486-499, doi:10.1016/j.atmosres.20'10.08.025, 2010.

McKendry, I., Strawbridge, K., Karumudi, M. L., O'Neill, N., Macdonald, A. M., Leaitch, R., Jaffe, D., Cottle, P., Sharma, S., Sheridan, P., and Ogren, J.A: Californian forest fire plumes over Southwestern British Columbia: lidar, sunphotometry, and mountaintop chemistry observations, Atmos. Chem. Phys., 11, 465-477, doi:10.5194/acp-11-465-2011, 2011.

Ogren, J. A.: A systematic approach to in situ observations of aerosol properties, in Aerosol forcing of climate, edited by: Charlson, R. J. and Heintzenberg, J., 215-226, John Wiley, Chichester, New York, USA, 1995.

Pace, G., di Sarra, A., Meloni, D., Piacentino, S., and Chamard, P.: Aerosol optical properties at Lampedusa (Central Mediterranean). 1. Influence of transport and identification of different aerosol types, Atmos. Chem. Phys., 6, 697-713, doi:10.5194/acp-6-697-2006, 2006.

Pahlow, M., Kleissl, J., Parlange, M. B., Ondov, J., and Harrison, D.: Atmospheric boundary layer structure as observed during a haze event due to forest fire smoke, Bound.-Layer Meteorol., 114, 53-70, 2005.

Pope, C. A., Burnett, R. T., Thun, M. J., Calle, E. E., Krewski, D., Ito, K., and Thurston, G. D.: Lung cancer, cardiopulmonary mortality, and long-term exposure to fine particulate air pollution, J. Am. Med. Assoc., 287, 1132-1141, 2002.

Reid, J. S., Eck, T. F., Christopher, S. A., Koppmann, R., Dubovik, O., Eleuterio, D. P., Holben, B. N., Reid, E. A., and Zhang, J.: A review of biomass burning emissions part III: intensive optical properties of biomass burning particles, Atmos. Chem. Phys., 5, 827-849, doi:10.5194/acp-5-827-2005, 2005.

RIMA, Red Iberica de la Medida fotométrica de Aerosoles (http://www.rima.uva.es), 2013.

Reutter, P., Su, H., Trentmann, J., Simmel, M., Rose, D., Gunthe, S. S., Wernli, H., Andreae, M. O., and Pöschl, U.: Aerosol- and updraft-limited regimes of cloud droplet formation: influence of particle number, size and hygroscopicity on the activation of cloud condensation nuclei (CCN), Atmos. Chem. Phys., 9, 7067-7080, doi:10.5194/acp-9-7067-2009, 2009.
ACPD

13, 22639-22685, 2013

Aerosol

microphysics and optical properties

J. L. Gómez-Amo et al.

Title Page

Abstract

Introduction

Conclusions

References

Tables

Figures

14

$\rightarrow 1$

4

Back

Close 
Rosenfeld, D., Lohmann, U., Raga, G. B., O’Dowd, G. D., Kulmala, M., Fuzzi, S., Reissell, A., and Andreae, M. O.: Flood or Drought: How Do Aerosols Affect Precipitation?, Science, 321, 1309-1313, 2008.

Salomonson, V., Barnes, W., Maymon, P., Montgomery, H., and Ostrow, H.: MODIS: advanced 5 facility instrument for studies of the Earth as a system, IEEE Trans. Geosci. Remote Sens., 27, 145-153, 1989.

Sasano, Y. and Nakane, H.: Significance of the extinction/backscatter ratio and the boundary value term in the solution for the two-component lidar equation, Appl. Opt., 23, 11-13, 1984.

Seinfeld, J. H. and Pandis, S. N.: Atmospheric Chemistry and Physics: From Air Pollution to Climate Change, 2nd edition, J. Wiley, New York, 350-384, 2006.

Smirnov, A., Holben, B. N., Eck, T. F., Dubovik, O., and Slutsker, I., Cloud-Screening and Quality Control Algorithms for the AERONET Database, Remote Sens. Environ., 73, 337-349, 2000.

Stone, R. S., Augustine, J. A., Dutton, E. G., O'Neill, N. T. and Saha, A.: Empirical determinations of the longwave and shortwave radiative forcing efficiencies of wildfire smoke, J. Geophys. Res., 116, D12207, doi:10.1029/2010JD015471, 2011.

Trentmann, J., Luderer, G., Winterrath, T., Fromm, M. D., Servranckx, R., Textor, C., Herzog, M., Graf, H.-F., and Andreae, M. O.: Modeling of biomass smoke injection into the lower stratosphere by a large forest fire (Part I): reference simulation, Atmos. Chem. Phys., 6, 5247-5260, doi:10.5194/acp-6-5247-2006, 2006. Geneva, 2002.

WHO: Health aspects of air pollution with particulate matter, ozone and nitrogen dioxide, World Health Organization, Bonn, 2003.

Yokelson, R. J., Urbanski, S. P., Atlas, E. L., Toohey, D. W., Alvarado, E. C., Crounse, J. D., Wennberg, P. O., Fisher, M. E., Wold, C. E., Campos, T. L., Adachi, K., Buseck, P. R., and Hao, W. M.: Emissions from forest fires near Mexico City, Atmos. Chem. Phys., 7, 55695584, doi:10.5194/acp-7-5569-2007, 2007.

\section{ACPD}

13, 22639-22685, 2013

\section{Aerosol}

microphysics and optical properties

J. L. Gómez-Amo et al.

\section{Title Page}

\section{Abstract}

Introduction

Conclusions

References

Tables

Figures

14

$\rightarrow$

4

Back

Close

Full Screen / Esc

Printer-friendly Version

Interactive Discussion 


\section{ACPD}

\section{3, 22639-22685, 2013}

Table 1. Daily averaged scattering coefficient and $\mathrm{PM}_{2.5}$ at ground level for the 11-days time window.

\begin{tabular}{lllllll}
\hline day & \multicolumn{3}{c}{ Scattering coefficient } & \multicolumn{3}{c}{$\mathrm{PM}_{2.5}$} \\
& $\begin{array}{l}\text { average } \pm \sigma \\
\left(M \mathrm{~m}^{-1}\right)\end{array}$ & $\begin{array}{l}\max \\
\left(\mathrm{M} \mathrm{m}^{-1}\right)\end{array}$ & $\begin{array}{l}\min \\
\left(\mathrm{M} \mathrm{m}^{-1}\right)\end{array}$ & $\begin{array}{l}\text { average } \pm \sigma \\
\left(\mu \mathrm{m} \mathrm{m}^{-3}\right)\end{array}$ & $\begin{array}{l}\max \\
\left(\mu \mathrm{g} \mathrm{m}^{-3}\right)\end{array}$ & $\begin{array}{l}\min \\
\left(\mu \mathrm{g} \mathrm{m}^{-3}\right)\end{array}$ \\
\hline $24 / 06 / 2012$ & $50 \pm 14$ & 81 & 31 & $18 \pm 6$ & 30 & 6 \\
$25 / 06 / 2012$ & $41 \pm 10$ & 77 & 23 & $14 \pm 5$ & 25 & 5 \\
$26 / 06 / 2012$ & $42 \pm 7$ & 59 & 27 & $19 \pm 5$ & 30 & 10 \\
$2706 / 2012$ & $55 \pm 11$ & 120 & 39 & $19 \pm 4$ & 25 & 13 \\
$28 / 06 / 2012$ & $90 \pm 21$ & 133 & 53 & $29 \pm 6$ & 44 & 21 \\
$29 / 06 / 2012$ & $221 \pm 88$ & 407 & 100 & $38 \pm 16$ & 77 & 19 \\
$30 / 06 / 2012$ & $306 \pm 130$ & 589 & 156 & $50 \pm 37$ & 166 & 20 \\
$01 / 07 / 2012$ & $277 \pm 367$ & 2098 & 26 & $50 \pm 37$ & 130 & 13 \\
$02 / 07 / 2012$ & $125 \pm 217$ & 1182 & 20 & $27 \pm 23$ & 85 & 2 \\
$03 / 07 / 2012$ & $82 \pm 39$ & 182 & 35 & $17 \pm 7$ & 29 & 2 \\
$04 / 07 / 2012$ & $85 \pm 17$ & 135 & 56 & $18 \pm 7$ & 29 & 4 \\
\hline
\end{tabular}

\section{Aerosol}

microphysics and optical properties

J. L. Gómez-Amo et al.

Title Page

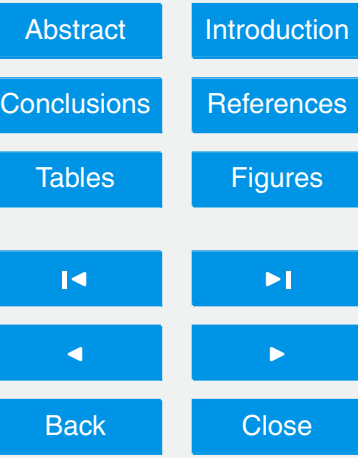

Full Screen / Esc

Printer-friendly Version

Interactive Discussion 


\section{ACPD}

13, 22639-22685, 2013

Table 2. Daily averaged refractive index by the AERONET inversions for the 11-days time window.

\begin{tabular}{llllll}
\hline Day & $N$ & \multicolumn{4}{c}{ refractive index } \\
& & $440 \mathrm{~nm}$ & $670 \mathrm{~nm}$ & $870 \mathrm{~nm}$ & $1020 \mathrm{~nm}$ \\
\hline $24 / 06 / 2012$ & 9 & $1.54-0.011 \mathrm{i}$ & $1.53-0.010 \mathrm{i}$ & $1.52-0.011 \mathrm{i}$ & $1.52-0.010 \mathrm{i}$ \\
$25 / 06 / 2012$ & 9 & $1.56-0.017 \mathrm{i}$ & $1.55-0.015 \mathrm{i}$ & $1.56-0.015 \mathrm{i}$ & $1.55-0.014 \mathrm{i}$ \\
$26 / 06 / 2012$ & 8 & $1.46-0.0053 \mathrm{i}$ & $1.48-0.0034 \mathrm{i}$ & $1.48-0.0036 \mathrm{i}$ & $1.47-0.0032 \mathrm{i}$ \\
$27 / 06 / 2012$ & 0 & & & & \\
$28 / 06 / 2012$ & 5 & $1.47-0.006 \mathrm{i}$ & $1.48-0.0016 \mathrm{i}$ & $1.47-0.0015 \mathrm{i}$ & $1.45-0.0014 \mathrm{i}$ \\
$29 / 06 / 2012$ & 1 & $1.51-0.004 \mathrm{i}$ & $1.51-0.002 \mathrm{i}$ & $1.50-0.003 \mathrm{i}$ & $1.49-0.002 \mathrm{i}$ \\
$30 / 06 / 2012$ & 0 & & & & \\
$01 / 07 / 2012$ & 2 & $1.54-0.015 \mathrm{i}$ & $1.53-0.014 \mathrm{i}$ & $1.53-0.014 \mathrm{i}$ & $1.52-0.013 \mathrm{i}$ \\
$02 / 07 / 2012$ & 0 & & & & \\
$03 / 07 / 2012$ & 0 & & & & \\
$04 / 07 / 2012$ & 4 & $1.52-0.009 \mathrm{i}$ & $1.52-0.009 \mathrm{i}$ & $1.53-0.009 \mathrm{i}$ & $1.53-0.008 \mathrm{i}$ \\
Smoke & & $1.54-0.015 \mathrm{i}$ & $1.53-0.014 \mathrm{i}$ & $1.53-0.014 \mathrm{i}$ & $1.52-0.013 \mathrm{i}$ \\
dust & & $1.46-0.0054 \mathrm{i}$ & $1.48-0.0028 \mathrm{i}$ & $1.48-0.0028 \mathrm{i}$ & $1.47+0.0025 \mathrm{i}$ \\
\hline
\end{tabular}

\section{Aerosol}

microphysics and optical properties

J. L. Gómez-Amo et al.

Title Page

Abstract

Introduction

Conclusions

References

Tables

Figures

14

DI

4

Back

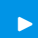

Close

Full Screen / Esc

Printer-friendly Version

Interactive Discussion 


\section{ACPD}

13, 22639-22685, 2013

Table 3. Daily averaged aerosol microphysics for the 11-days time window considering the aerosol type.

\begin{tabular}{|c|c|c|c|c|c|c|c|c|c|c|}
\hline \multirow[t]{2}{*}{ aerosol type } & \multirow[t]{2}{*}{ Day } & \multicolumn{2}{|c|}{ Total } & \multicolumn{3}{|c|}{ Fine } & \multicolumn{3}{|c|}{ Coarse } & \multirow[t]{2}{*}{ FMF } \\
\hline & & $V_{T}$ & $r_{\text {effT }}$ & $V_{F}$ & $\sigma_{\mathrm{F}}$ & $r_{\mathrm{vF}}$ & $v_{\mathrm{c}}$ & $\sigma_{\mathrm{C}}$ & $r_{\mathrm{vC}}$ & \\
\hline summer background & $\begin{array}{l}24 / 06 / 2012 \\
25 / 06 / 2012\end{array}$ & $\begin{array}{l}0.061 \pm 0.006 \\
0.061 \pm 0.005\end{array}$ & $\begin{array}{l}0.31 \pm 0.03 \\
0.325 \pm 0.019\end{array}$ & $\begin{array}{l}0.0194 \pm 0.0015 \\
0.0190 \pm 0.0018\end{array}$ & $\begin{array}{l}1.491 \pm 0.018 \\
1.491 \pm 0.018\end{array}$ & $\begin{array}{l}0.1179 \pm 0.0014 \\
0.1190 \pm 0.0014\end{array}$ & $\begin{array}{l}0.042 \pm 0.006 \\
0.042 \pm 0.004\end{array}$ & $\begin{array}{l}1.983 \pm 0.017 \\
2.004 \pm 0.012\end{array}$ & $\begin{array}{l}2.42 \pm 0.15 \\
2.48 \pm 0.15\end{array}$ & $\begin{array}{l}0.32 \pm 0.04 \\
0.31 \pm 0.02\end{array}$ \\
\hline dust & $\begin{array}{l}26 / 06 / 2012 \\
27 / 06 / 2012 \\
28 / 06 / 2012 \\
29 / 06 / 2012 \\
30 / 06 / 2012\end{array}$ & $\begin{array}{l}0.206 \pm 0.06 \\
0.314 \pm 0.013 \\
0.35 \pm 0.04 \\
0.33 \pm 0.05 \\
0.24 \pm 0.016\end{array}$ & $\begin{array}{l}0.50 \pm 0.10 \\
0.64 \pm 0.02 \\
0.78 \pm 0.07 \\
0.72 \pm 0.16 \\
0.60 \pm 0.02\end{array}$ & $\begin{array}{l}0.035 \pm 0.004 \\
0.0401 \pm 0.0010 \\
0.033 \pm 0.006 \\
0.038 \pm 0.011 \\
0.036 \pm 0.005\end{array}$ & $\begin{array}{l}1.66 \pm 0.05 \\
1.702 \pm 0.015 \\
1.79 \pm 0.02 \\
1.69 \pm 0.05\end{array}$ & $\begin{array}{l}0.136 \pm 0.012 \\
0.151 \pm 0.003 \\
0.180 \pm 0.005 \\
0.153 \pm 0.012 \\
0.1491 \pm 0.0013\end{array}$ & $\begin{array}{l}0.17 \pm 0.06 \\
0.274 \pm 0.014 \\
0.32 \pm 0.04 \\
0.29 \pm 0.05 \\
0.202 \pm 0.011\end{array}$ & $\begin{array}{l}1.90 \pm 0.06 \\
1.834 \pm 0.016 \\
1.784 \pm 0.015 \\
1.82 \pm 0.11 \\
1.91 \pm 0.04\end{array}$ & $\begin{array}{l}1.87 \pm 0.13 \\
1.79 \pm 0.04 \\
1.6190 \pm 0.14 \\
1.9537 \pm 0.14 \\
2.0507 \pm 0.12\end{array}$ & $\begin{array}{l}0.18 \pm 0.04 \\
0.13 \pm 0.008 \\
0.095 \pm 0.012 \\
0.119 \pm 0.04 \\
0.15 \pm 0.012\end{array}$ \\
\hline smoke & $\begin{array}{l}28 / 06 / 2012 \\
29 / 06 / 2012 \\
30 / 06 / 2012 \\
01 / 07 / 2012\end{array}$ & $\begin{array}{l}0.67 \pm 0.03 \\
0.50 \pm 0.17 \\
0.30 \pm 0.03 \\
0.114 \pm 0.010\end{array}$ & & & & & & & & $\begin{array}{l}0.14 \pm 0.04 \\
0.58 \pm 0.16 \\
0.43 \pm 0.14 \\
0.52 \pm 0.03\end{array}$ \\
\hline residual smoke & $\begin{array}{l}02 / 07 / 2012 \\
03 / 07 / 2012 \\
04 / 07 / 2012\end{array}$ & $\begin{array}{l}0.117 \pm 0.013 \\
0.141 \pm 0.014 \\
0.126 \pm 0.018\end{array}$ & $\begin{array}{l}0.35 \pm 0.02 \\
0.38 \pm 0.02 \\
0.35 \pm 0.03\end{array}$ & $\begin{array}{l}0.034 \pm 0.003 \\
0.036 \pm 0.003 \\
0.035 \pm 0.005\end{array}$ & $\begin{array}{l}1.53 \pm 0.03 \\
1.52 \pm 0.03 \\
1.475 \pm 0.019\end{array}$ & $\begin{array}{l}0.122 \pm 0.002 \\
0.122 \pm 0.003 \\
0.120 \pm 0.0003\end{array}$ & $\begin{array}{l}0.083 \pm 0.010 \\
0.105 \pm 0.013 \\
0.091 \pm 0.015\end{array}$ & $\begin{array}{l}1.98 \pm 0.05 \\
1.92 \pm 0.06 \\
1.94 \pm 0.05\end{array}$ & $\begin{array}{l}2.63 \pm 0.14 \\
2.7 \pm 0.2 \\
2.72 \pm 0.11\end{array}$ & $\begin{array}{l}0.29 \pm 0.019 \\
0.26 \pm 0.03 \\
0.28 \pm 0.03\end{array}$ \\
\hline
\end{tabular}

Title Page

Abstract

Conclusions

Tables

14

4

Back

\section{Aerosol}

microphysics and optical properties

J. L. Gómez-Amo et al.

Introduction

References

\section{Figures}

$>$

Close

Full Screen / Esc

Printer-friendly Version

Interactive Discussion 


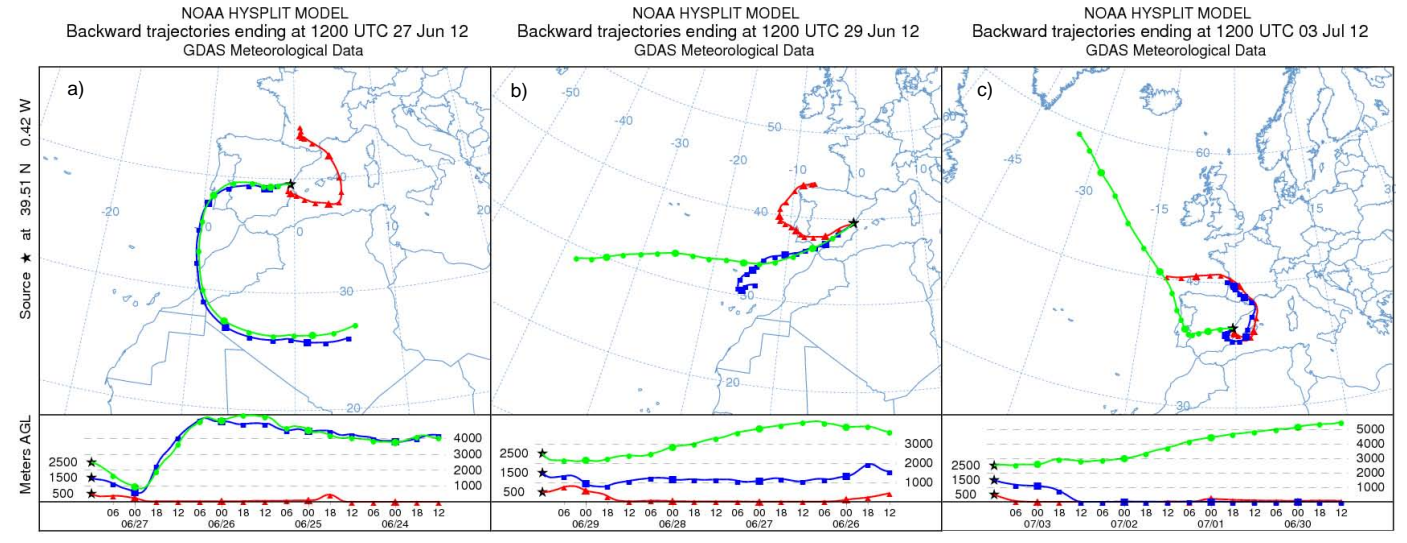

Fig. 1. HYSPLIT back trajectories ending at 12:00 UTC at Burjassot for: (a) 27 June, (b) 29 June, (c) 3 July.

\section{ACPD}

13, 22639-22685, 2013

Aerosol

microphysics and optical properties

\section{J. L. Gómez-Amo et al.}

\section{Title Page}

Abstract

Introduction

Conclusions

References

Tables

Figures

$1<$

$>1$

4

Back

$>$

\section{Full Screen / Esc}

Printer-friendly Version

Interactive Discussion

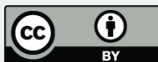




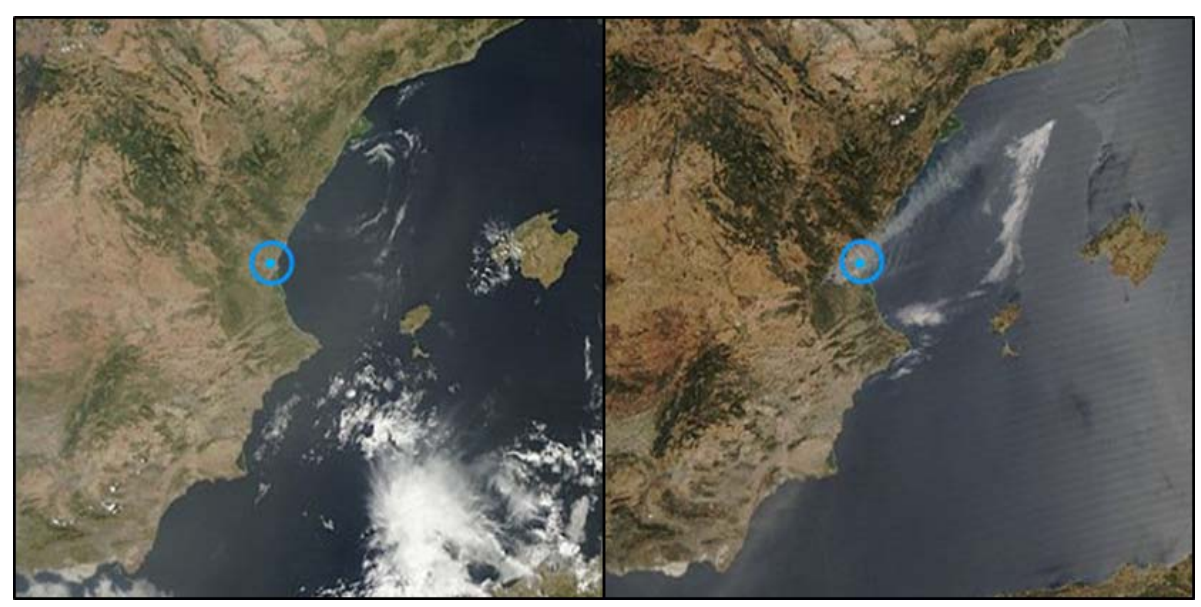

Fig. 2. MODIS Quick response images: (a) before the start of wildfire (28 June at 12:00:00 UTC) and (b) the most intense day of the wildfire event (29 June at 13:05:00 UTC). The location of Burjassot station is indicated by the blue dot.

\section{ACPD}

13, 22639-22685, 2013

\section{Aerosol}

microphysics and optical properties

J. L. Gómez-Amo et al.

Title Page

Abstract

Introduction

Conclusions

References

Tables

Figures

14

DI

4

Back

Close

\section{Full Screen / Esc}

Printer-friendly Version

Interactive Discussion 


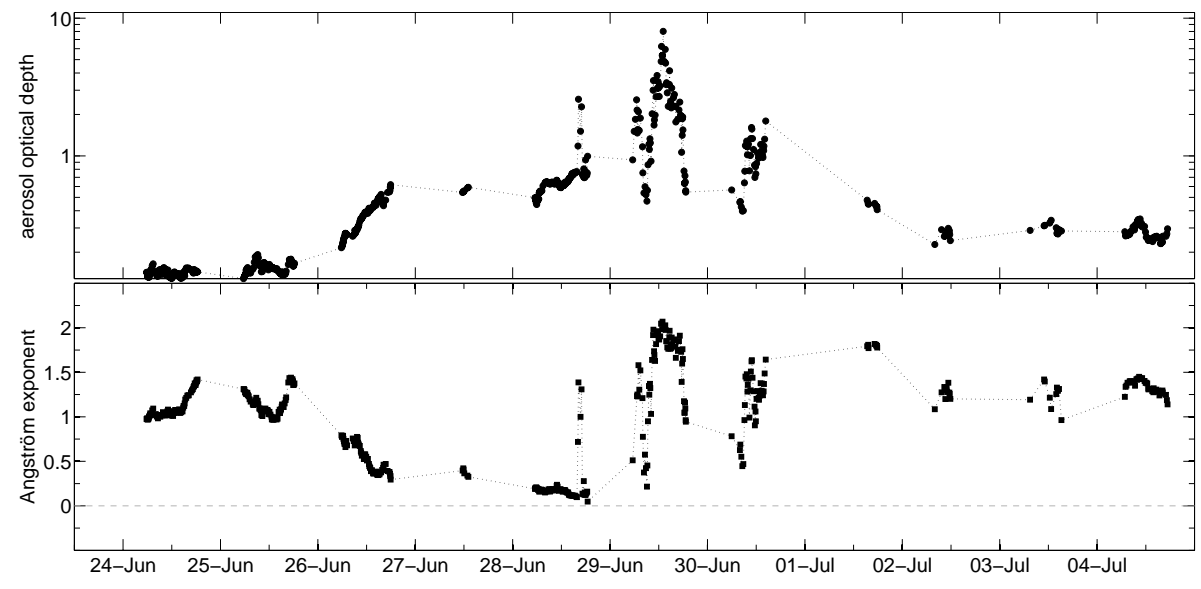

\section{ACPD}

13, 22639-22685, 2013

\section{Aerosol}

microphysics and optical properties

\section{J. L. Gómez-Amo et al.}

Title Page

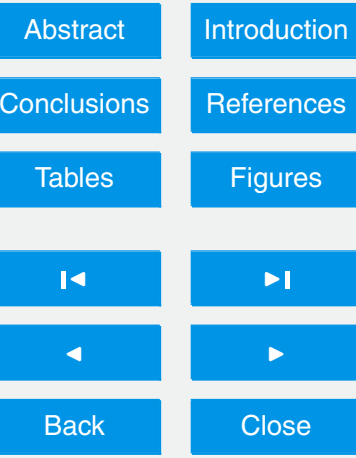

Full Screen / Esc

Printer-friendly Version

Interactive Discussion

(c) (1) 
a)

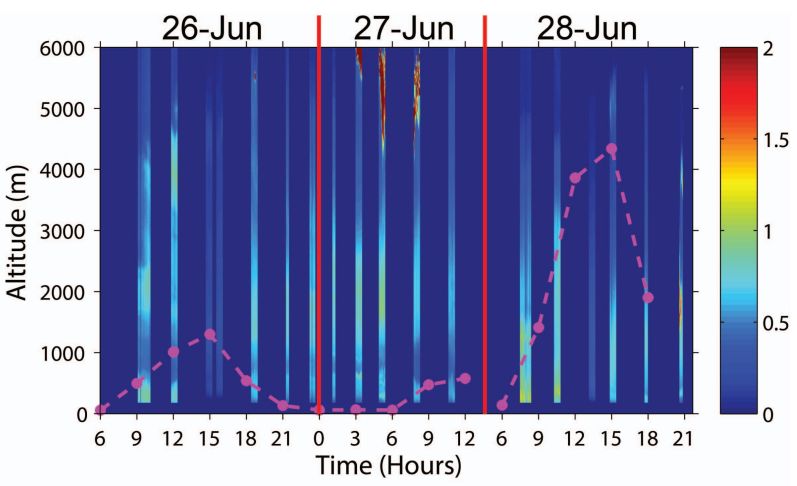

b)

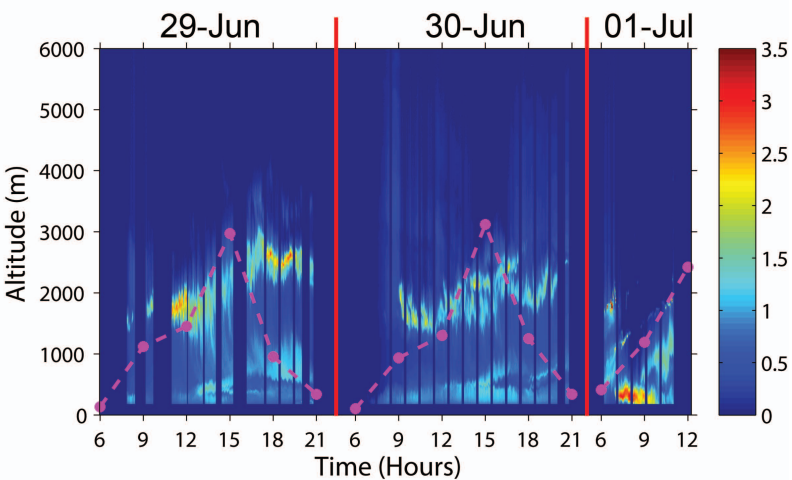

Fig. 4. Measurements of the lidar range corrected signal during the studied temporal window: (a) 26-28 June; and (b) 29 June-1 July. The mixing layer height from HYSPLIT model is overlapped (dotted pink line).

\section{ACPD}

13, 22639-22685, 2013

Aerosol

microphysics and optical properties

\section{J. L. Gómez-Amo et al.}

Title Page

Abstract

Introduction

Conclusions

References

Tables

Figures

14

$>1$

4

Back

$>$

Close 


\section{ACPD}

13, 22639-22685, 2013

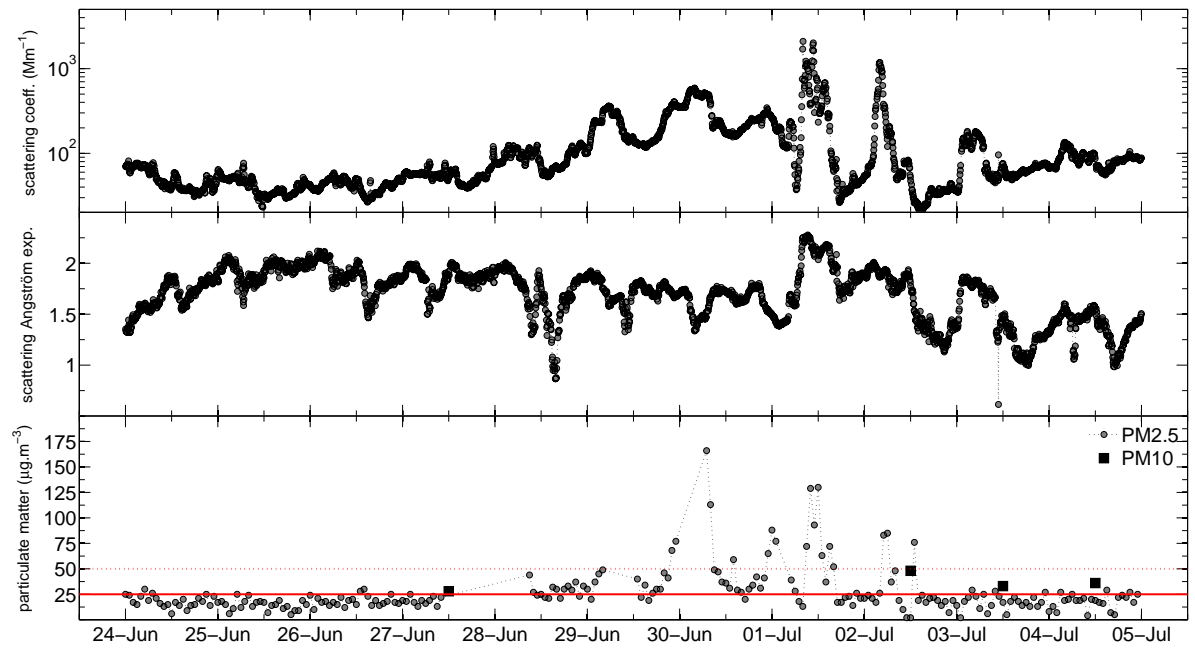

\section{Aerosol}

microphysics and optical properties

\section{J. L. Gómez-Amo et al.}

Title Page

Fig. 5. Time series of in situ surface measurements during the 11-day time window: (a) aerosol scattering coefficient at $550 \mathrm{~nm}$; (b) Ångström exponent of scattering and (c) particulate matter levels $\mathrm{PM}_{2.5}$ and $\mathrm{PM}_{10}$. The red lines represent the EU limits for $\mathrm{PM}_{2.5}$ (dotted) and $\mathrm{PM}_{10}$ (solid) levels.

4

Back
$>$

Close

\section{Full Screen / Esc}

Printer-friendly Version

Interactive Discussion 


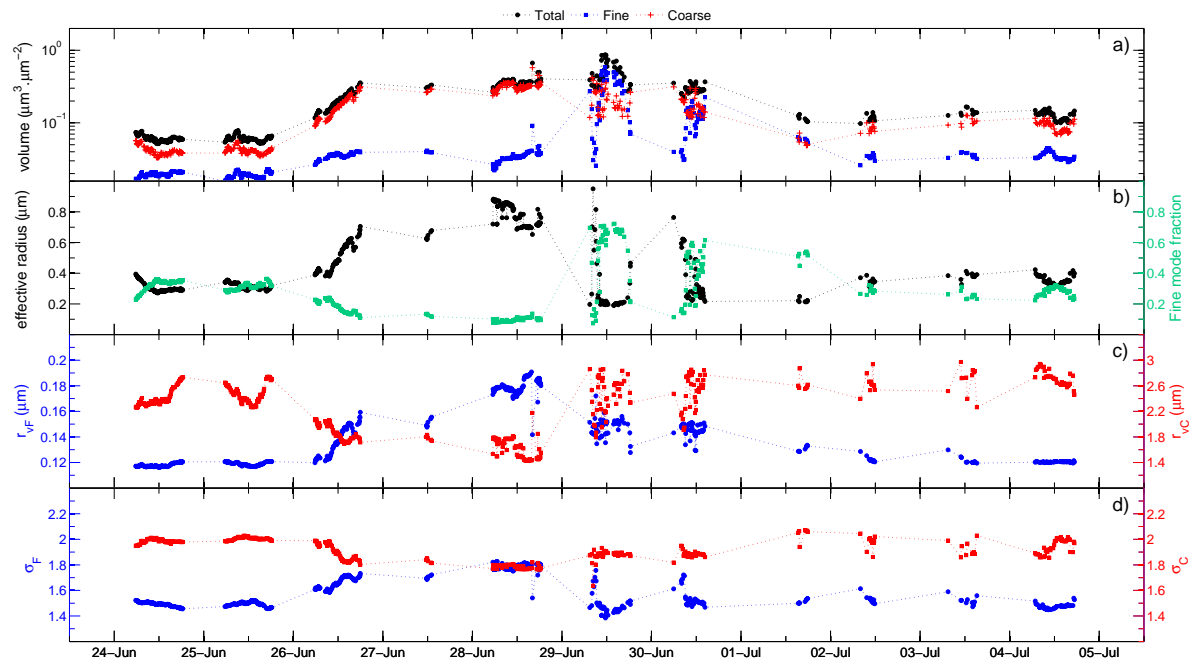

Fig. 6. Time series of the aerosol microphysics during the 11-days time window for the total (black dots), fine (blue squares) and coarse (red crosses) modes: (a) volume concentration; (b) effective radius and FMF (green); c) volume median radius for fine $\left(r_{\mathrm{vF}}\right)$ and coarse $\left(r_{\mathrm{vC}}\right)$ modes; and (d) standard deviation for fine $\left(\sigma_{\mathrm{F}}\right)$ and coarse $\left(\sigma_{\mathrm{C}}\right)$ modes.
ACPD

13, 22639-22685, 2013

\section{Aerosol}

microphysics and optical properties

J. L. Gómez-Amo et al.

Title Page

Abstract

Introduction

Conclusions

References

Tables

Figures

14

$\rightarrow 1$

4

Back

Close

Full Screen / Esc

Printer-friendly Version

Interactive Discussion 

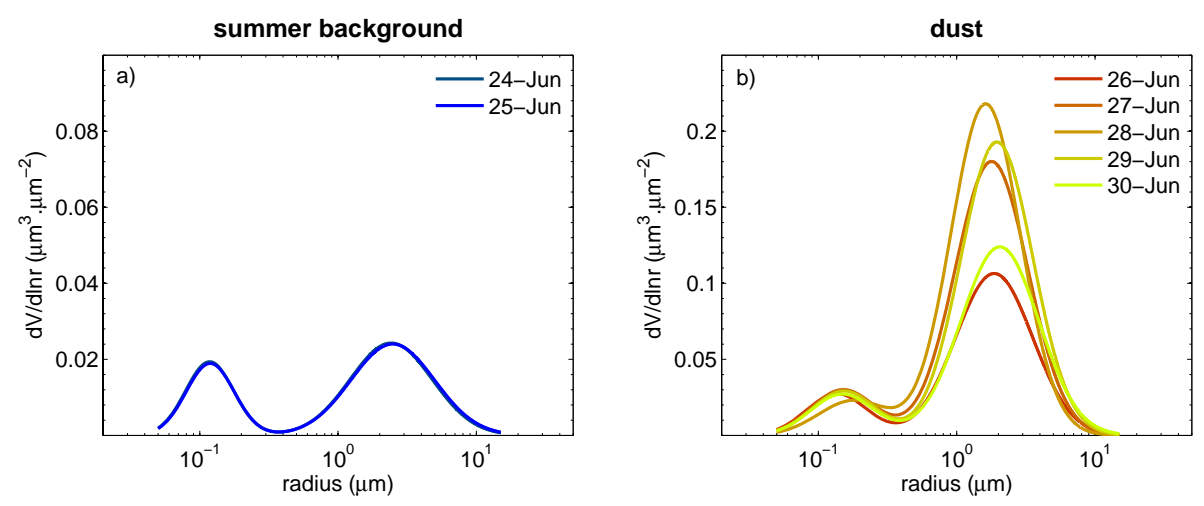

\section{ACPD}

13, 22639-22685, 2013
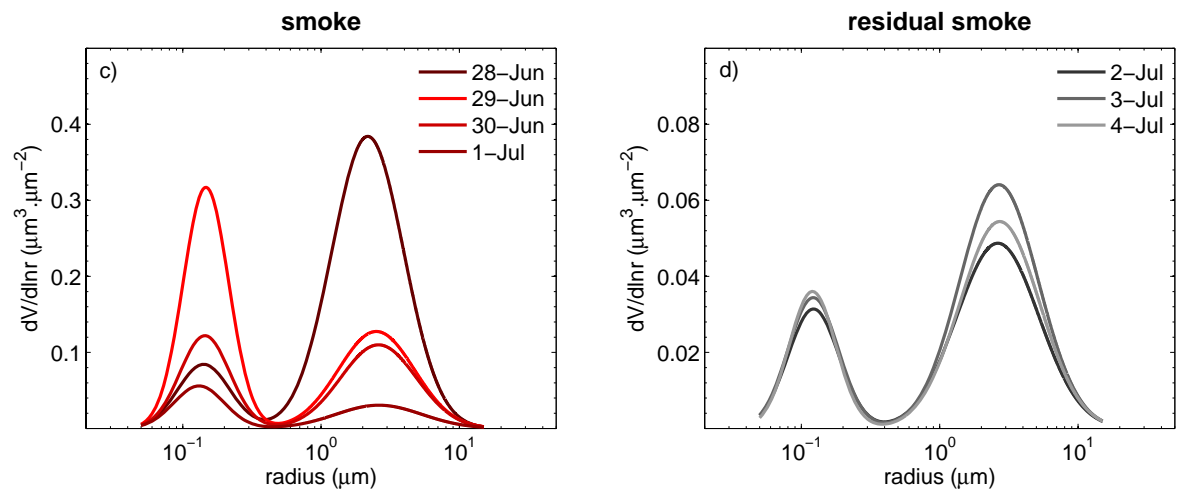

Title Page

4

\section{Back}

>

\section{Full Screen / Esc}

Printer-friendly Version

Fig. 7. Daily averaged aerosol size distributions for the different aerosol types found during the 11-days time window: (a) summer background; (b) dust; (c) smoke and (d) residual smoke. 


\section{ACPD}

13, 22639-22685, 2013
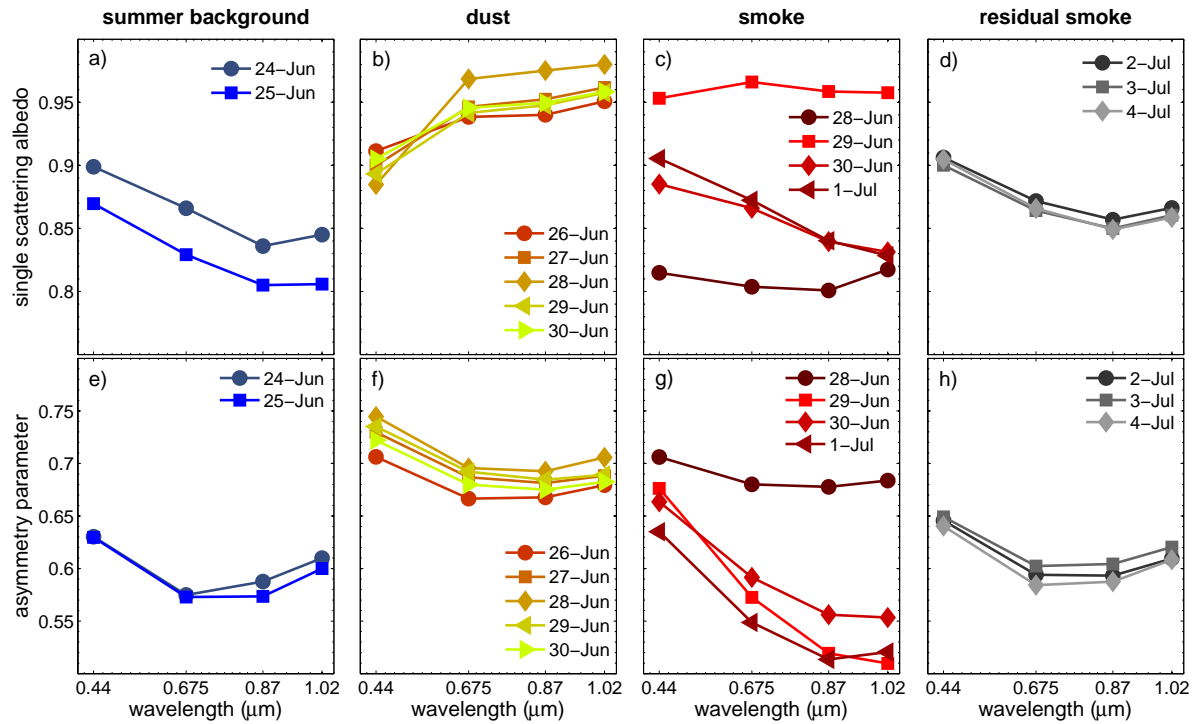

Fig. 8. Spectral dependence of the aerosol optical properties for the different aerosol types identified during the 11-days time window: (a) single scattering albedo and (b) asymmetry parameter.

\section{Aerosol}

microphysics and optical properties

\section{J. L. Gómez-Amo et al.}

\section{Title Page}

Abstract

Introduction

Conclusions

References

Tables

Figures

14

$>1$

4

Back

$>$

Close

\section{Full Screen / Esc}

Printer-friendly Version

Interactive Discussion 